\title{
Diverse Amino Acid Changes at Specific Positions in the N-Terminal Region of the Coat Protein Allow Plum pox virus to Adapt to New Hosts
}

\author{
Alberto Carbonell, Varvara I. Maliogka, José de Jesús Pérez, Beatriz Salvador, David San León, \\ Juan Antonio García, and Carmen Simón-Mateo \\ Departamento de Genética Molecular de Plantas, Centro Nacional de Biotecnología (CNB-CSIC), Campus Universidad \\ Autónoma de Madrid, 28049 Madrid, Spain
}

Submitted 3 April 2013. Accepted 25 May 2013.

\begin{abstract}
Plum pox virus (PPV)-D and PPV-R are two isolates from strain D of PPV that differ in host specificity. Previous analyses of chimeras originating from PPV-R and PPV-D suggested that the $\mathbf{N}$ terminus of the coat protein $(\mathrm{CP})$ includes host-specific pathogenicity determinants. Here, these determinants were mapped precisely by analyzing the infectivity in herbaceous and woody species of chimeras containing a fragment of the $3^{\prime}$ region of PPV-D (including the region coding for the $\mathrm{CP}$ ) in a PPV-R backbone. These chimeras were not infectious in Prunus persica, but systemically infected Nicotiana clevelandii and $N$. benthamiana when specific amino acids were modified or deleted in a short 30-amino-acid region of the $\mathrm{N}$ terminus of the $\mathrm{CP}$. Most of these mutations did not reduce PPV fitness in Prunus spp. although others impaired systemic infection in this host. We propose a model in which the $\mathbf{N}$ terminus of the $\mathrm{CP}$, highly relevant for virus systemic movement, is targeted by a host defense mechanism in Nicotiana spp. Mutations in this short region allow PPV to overcome the defense response in this host but can compromise the efficiency of PPV systemic movement in other hosts such as Prunus spp.
\end{abstract}

Plum pox virus (PPV) is considered as one of the most important plant viruses (Scholthof et al. 2011). It causes sharka, a devastating disease that affects nearly all species of the genus Prunus (García and Cambra 2007; Sochor et al. 2012). PPV is a member of the genus Potyvirus of the Potyviridae family (López-Moya et al. 2009), and has a single-

\section{A. Carbonell and V. I. Maliogka contributed equally to this work}

Current address for A. Carbonell: Donald Danforth Plant Science Center, 975 N. Warson Rd., St. Louis 63132.

Current address for V. I. Maliogka: Plant Pathology Laboratory, School of Agriculture, Aristotle University of Thessaloniki, 54124 Thessaloniki, Greece.

Current address for B. Salvador: Blood Systems Research Institute, 270 Masonic Ave., San Francisco 94118.

Corresponding authors: J. Antonio García; E-mail: jagarcia@cnb.csic.es; and C. Simón-Mateo; E-mail: csimon@cnb.csic.es

* The $\boldsymbol{e}$-Xtra logo stands for "electronic extra" and indicates that four supplementary figures and three supplementary tables are published online and that Figures 2, 3, 4, 5, and 6 appear in color online.

(c) 2013 The American Phytopathological Society stranded RNA genome of 9,786 nucleotides. Its genomic RNA is translated into a single polyprotein and a truncated frameshift product that are proteolytically processed by three self-encoded proteases (Chung et al. 2008; Salvador et al. 2006). RNA-dependent RNA polymerases are responsible for the replication of the genomic RNA, and cause high mutation rates due to lack of proofreading activity (Malpica et al. 2002). As a consequence, heterogeneous virus populations of closely related genomes or "quasispecies" coexist in the host plant during infection (Biebricher and Eigen 2006; Domingo and Holland 1997; Eigen 1996). However, virus populations retain a consensus sequence that can rapidly evolve depending on the environmental conditions and ultimately lead to new consensus sequences. Importantly, the modification of the consensus sequence of a virus population may also modify its pathogenicity (Domingo and Holland 1997). This feature makes these pathogens cause the occurrence of new emerging diseases, which is a major problem in agriculture (Elena et al. 2011; Jones 2009). In recent years, agricultural activity has undergone devastating epidemics caused by new viruses that have switched host species. In fact, the expansion in natural host range is considered one of the major factors driving emergence of new diseases (Jones 2009). However, the molecular mechanisms that determine how plant viruses establish successful infections in a certain host are still largely unknown.

Pathogenicity determinants in Potyvirus spp., including PPV, are spread throughout the viral genome. Several viral products such as P1 (Maliogka et al. 2012; Nagyova et al. 2012; Nakahara et al. 2010; Valli et al. 2007), HCPro (Carbonell et al. 2012; Faurez et al. 2012; Moury et al. 2011; Sáenz et al. 2001), P3+6K1 (Dallot et al. 2001; Hjulsager et al. 2006; Jenner et al. 2003; Sáenz et al. 2000; Suehiro et al. 2004; Wen et al. 2011), CI (Abdul-Razzak et al. 2009; Seo et al. 2009; Zhang et al. 2009), 6K2 (Spetz and Valkonen 2004), NIa-VPg (Keller et al. 1998; Masuta et al. 1999; Moury et al. 2004), NIa-Pro (Chen et al. 2008), NIb (Fellers et al. 2002; Gallois et al. 2010; Wallis et al. 2007), and the coat protein (CP) (Andersen and Johansen 1998; Decroocq et al. 2009; Salvador 2008), as well as the 5' and $3^{\prime}$ noncoding regions (Rodríguez-Cerezo et al. 1991; Simón-Buela et al. 1997), have been reported to contain pathogenicity determinants, which play different roles in all steps of the viral infection (Revers et al. 1999). Analyses of the infectivity of chimeras generated from viruses with different biological properties have been a useful tool for the identification of virus-specific pathogenicity and host-range determinants. Thus, in the case of PPV, complex pathogenicity determinants were identified in herbaceous and woody hosts by using chim- 
eric cDNA clones generated first from the PPV-R and PPV-PS isolates, belonging to two different PPV strains (Sáenz et al. 2000), and then more precisely from the PPV-R and PPV-D isolates, both belonging to the PPV-D strain (Salvador et al. 2008). PPV-R infects herbaceous hosts but has lost the ability to infect Prunus spp. after extended propagation in herbaceous plants (Dallot et al. 2001), whereas PPV-D systemically infects Prunus spp. but not herbaceous hosts (Salvador et al. 2008). The analysis of chimeras originating from PPV-R and PPV-D demonstrated that, although pathogenicity determinants are extensively spread throughout the PPV genome, relevant host-specific determinants are located at the $\mathrm{N}$ terminus of the $\mathrm{CP}$ (Salvador et al. 2008). Moreover, the determinant of potyvirus ability to overcome the restricted Tobacco etch virus movement (RTM) resistance of Arabidopsis thaliana also mapped to the Nterminal region of the CP (Decroocq et al. 2009).

Here, we have further explored the pathogenicity determinants contained in the $3^{\prime}$ end of PPV genome that are related to host adaptation. Our results show that specific amino acid substitutions or a 30-amino-acid (aa) deletion at the $\mathrm{N}$ terminus of the CP allow PPV to systemically infect herbaceous hosts with or without reducing its fitness in peach seedlings. The possible mechanisms by which these mutations could affect $\mathrm{CP}$ interactions with host factors to promote efficient long-distance movement of the virus or to induce host defenses are discussed.

\section{RESULTS}

\section{Infectivity of PPV-D and -R chimeric viruses} in woody and herbaceous hosts.

Previous studies with chimeric viruses between PPV-R and PPV-D, two isolates with high sequence similarity but different host specificity, showed that host-specific pathogenicity determinants are largely spread throughout the viral genome (Salvador et al. 2008). To further dissect such determinants, cDNA clones of two new chimeras, PPV-BSD and PPV-BND, were constructed. In these chimeras, a fragment of the $3^{\prime}$ region of the genome of PPV-R including the partial or total CP coding sequence was replaced by the corresponding fragment of PPV-D, in a PPV-R backbone (Fig. 1). Clones expressing PPV-R, PPVDc (a variant of PPV-D), and the Nicotiana spp.-infecting R/D chimera PPV-SBD were previously described (Salvador et al. 2008) and used here as controls (Fig. 1). The infectivity of the different clones was tested in woody and herbaceous hosts. In all cases, virus-induced symptoms were monitored, and virus accumulation levels were measured by enzyme-linked immunosorbent assay (ELISA) or Western blot analyses.

First, infectivity experiments in Prunus persica GF305 seedlings showed that only seedlings inoculated with PPV-Dc but

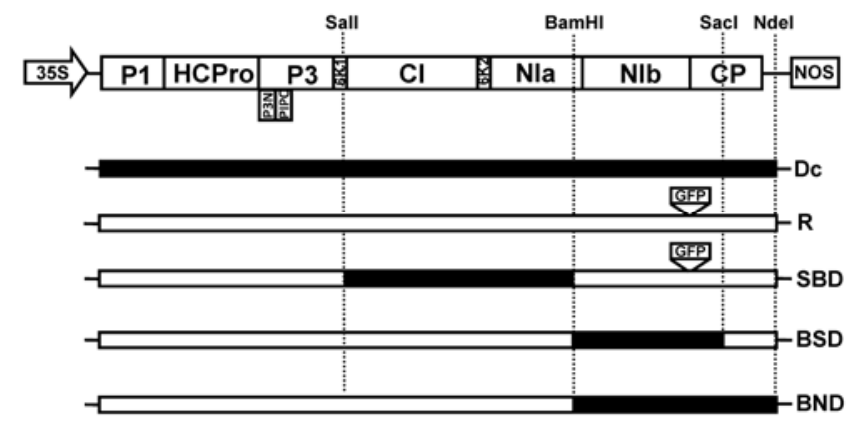

Fig. 1. Schematic representation of Plum pox virus (PPV) cDNA clones Dc (in black), R (in white), and PPV-R/D hybrids constructed from them. Positions of the restriction sites used for the cloning of the hybrids are highlighted with vertical dotted lines. The green fluorescent protein (GFP) sequence is represented with a box between NIb and coat protein $(\mathrm{CP})$. not with PPV-SBD, PPV-BND, or PPV-BSD showed symptoms at 21 days postinoculation (dpi) (Table 1). ELISA analysis of upper leaves at 30 dpi confirmed that PPV was only detected in those seedlings inoculated with PPV-Dc (Table 1).

Next, the infectivity of the PPV-D or -R hybrids was assessed in two Nicotiana spp., Nicotiana clevelandii and N. benthamiana. These species are common experimental hosts used for PPV studies, although neither of them is systemically infected by PPV-Dc. In a first bioassay, four $N$. clevelandii plants were inoculated with PPV-BND, PPV-BSD, or the PPV-SBD control chimera. At $21 \mathrm{dpi}$, all four plants inoculated with PPVSBD showed leaf chlorosis as a consequence of viral infection (Table 1). At this time, all the plants inoculated with PPV-BSD or PPV-BND showed neither disease symptoms nor viral accumulation by ELISA analysis. However, at $27 \mathrm{dpi}$, one plant inoculated with PPV-BND and one plant inoculated with PPVBSD showed leaf chlorosis symptoms in upper leaves. These symptoms were similar to those of plants infected with PPVSBD (Fig. 2A; Table 1). Virus accumulation in the symptomatic plants and in two asymptomatic plants inoculated with PPV-BSD was detected by Western blot analysis from extracts of upper leaves at $27 \mathrm{dpi}$ (Fig. 2B). However, CP levels in PPV-BND- or PPV-BSD-infected plants were variable, and lower than those of plants infected with PPV-SBD. Thus, these results show that both PPV-BND and PPV-BSD chimeras have low infectivity rates, and virus accumulation is delayed. Next, we analyzed the sequence of the PPV-D-derived genomic region of virus progenies accumulating in upper noninoculated leaves of those plants that became infected with PPV-BND and PPV-BSD. This analysis indicated the presence of the following amino acid substitutions in the $\mathrm{N}$ terminus of the $\mathrm{CP}$ : i) Ile at position 16 was mutated to Val in a PPV-BSD-infected plant and in the only PPV-BND-infected plant, ii) Asp in position 11 was mutated to a Gly in another PPV-BSD-infected plant, and iii) amino acids from positions 7 to 36 were deleted in the third PPV-BSD-infected plant (Fig. 2B; Table 1). To further confirm and extend these results, in a second bioassay, 30 additional plants were inoculated with PPV-BSD. PPV-BSD and not PPV-BND was selected for further studies because it was the most infectious chimera (Fig. 2B; Table 1). Almost half of the plants inoculated with PPV-BSD were systemically infected and showed a diverse range of symptom intensity and virus accumulation (Table 1). Sequencing of virus progenies accumulating in the upper leaves of the infected plants showed, in all cases, the presence of mutations in a 30-aa region at the $\mathrm{N}$ terminus of the viral $\mathrm{CP}$ (Table 1). In summary, five amino acid changes (D11G, I16S, I16V, I16T, and V18A) and one deletion $(\Delta 7-36)$ were found in the $N$ terminus of the $\mathrm{CP}$ of viral progenies in $N$. clevelandii. The most frequent mutation was V18A (Table 1).

The infectivity of PPV-BSD chimera was next analyzed in $N$. benthamiana. Symptom development, virus accumulation, and sequence of the $\mathrm{N}$ terminus of the $\mathrm{CP}$ were analyzed to verify whether or not mutations could also be selected in the inoculated tissue. In a first bioassay, both PPV-R and PPV-Dc were able to replicate in the inoculated leaves but PPV-R accumulated at higher levels (Fig. 3B). PPV-BSD accumulated at intermediate levels, higher than PPV-Dc, although virus accumulation was variable (Fig. 3B). In all cases, virus progenies accumulating in the inoculated leaves maintained the parental sequence of the $\mathrm{N}$ terminus of the $\mathrm{CP}$ (Fig. 3B). Neither symptoms nor viral $\mathrm{CP}$ could be detected in the upper leaves of plants inoculated with PPV-Dc (Fig. 3A and B). However, at $21 \mathrm{dpi}$, two of the three plants inoculated with PPV-BSD displayed characteristic viral symptoms such as stunting and leaf chlorosis, although milder than those observed in plants infected with PPV-R (Fig. 3A). Indeed, all those plants inoculated with 
PPV-BSD showing symptoms accumulated virus $\mathrm{CP}$ as observed by Western blot. Interestingly, virus accumulation levels in upper leaves did not correlate with those detected in the inoculated leaves (Fig. 3B). As in N. clevelandii, sequencing of the virus progenies accumulating in the upper leaves of plants infected with PPV-BSD showed mutations in the $\mathrm{N}$ terminus of the viral CP (Fig. 3B). In a second bioassay, 27 additional plants were inoculated with PPV-BSD. Thirteen of these new plants were systemically infected (Table 1). Three of the amino acid changes detected in BSD-infected $N$. clevelandii plants (I16V, I16T, and V18A) were also identified in the progeny of some PPV-BSD-infected $N$. benthamiana plants (Table 1). In addition, a Lys to Arg mutation at position 14 was also detected in the virus that systemically spread in one $N$. benthamiana plant. In contrast to $N$. clevelandii, in $N$. benthamiana, some of the virus progenies were able to systemically move without introducing any mutations at the $\mathrm{N}$ terminus of their CP (Table 1). The symptomatology of plants infected with a chimeric virus lacking mutations was in general mild and the virus accumulation rather low compared with that of chimeras with amino acid changes (Table 1).

The infectivity of PPV-BSD chimera was also evaluated in two ecotypes of $A$. thaliana, Col-0 and Ler, that are known to have different susceptibility to diverse PPV isolates (Decroocq et al. 2006) (Supplementary Fig. S1; Table 1). At 40 dpi, none of the Col-0 and Ler plants inoculated with either PPV-Dc or PPV-BSD displayed symptoms of infection. In contrast, all Col-0 and Ler plants inoculated with PPV-R displayed strong leaf chlorosis. Western blot analyses of upper noninoculated leaves revealed that PPV-R accumulated to high levels in both Col-0 and Ler plants. In contrast, no viral CP was detected in any of the eight plants inoculated with PPV-Dc. Viral CP was not detected in any of the Col-0 and Ler plants inoculated with PPV-BSD except for one Ler plant. In this plant, no mutations were found in the CP coding sequence of the virus progeny.

In summary, these results indicate that i) the $3^{\prime}$ end of PPVD genome is not sufficient to confer PPV the ability to infect P. persica; ii) PPV chimeras containing sequences from the $3^{\prime}$ end of the PPV-D genome can systemically infect $N$. clevelandii, provided that the $\mathrm{N}$ terminus of the $\mathrm{CP}$ sequence is modified; and iii) the PPV-BSD chimera can occasionally systemically infect $N$. benthamiana without modifying the $\mathrm{N}$ terminus of the $\mathrm{CP}$ sequence, although mutations at this region are also usually selected in this host.

\section{Stability of the mutations detected in the progeny of PPV-BSD.}

Next, a second round of PPV-BSD infections was performed. The aim was to assess the stability of the mutations introduced during the adaptation process of PPV-BSD in herbaceous plants and their effect on the overall fitness of the virus. Healthy $N$. clevelandii or $N$. benthamiana plants were inoculated with extracts of the plants primarily infected with PPV-BSD (Tables 2 and 3 ).

In the two Nicotiana spp., most of the mutated progenies of PPV-BSD (from either $N$. clevelandii or $N$. benthamiana plants) infected all the inoculated plants and accumulated large amounts of virus. Moreover, they conserved the original muta-

Table 1. Phenotypic and molecular analyses of Plum pox virus (PPV)-D/R hybrids in different plant hosts

\begin{tabular}{|c|c|c|c|c|}
\hline Host, PPV variant & Infectivity $^{\mathrm{a}}$ & Amino acid changes & Symptoms ${ }^{c}$ & Virus accumulation $^{\mathrm{d}}$ \\
\hline \multicolumn{5}{|l|}{ Prunus persica } \\
\hline BND & $0 / 4$ & _- & _- & - \\
\hline BSD & $0 / 4$ & _- & _- & _- \\
\hline Dc & $4 / 4$ & - & +++ & +++ \\
\hline SBD & $0 / 4$ & - & - & - \\
\hline \multicolumn{5}{|l|}{ Nicotiana clevelandii } \\
\hline BND & $1 / 4$ & I16V (1) & +++ & + \\
\hline \multirow{6}{*}{$\mathrm{BSD}^{\mathrm{e}}$} & $16 / 34$ & $\Delta 7-36(1)$ & - & + \\
\hline & & $\mathrm{D} 11 \mathrm{G}(1)$ & - $\quad$ & + \\
\hline & & $\operatorname{I16S}(3)$ & $+(1),-(2)$ & $+++(1),++(1), \pm(1)$ \\
\hline & & I16T (3) & $+(1),-(2)$ & $+++(1),+(2)$ \\
\hline & & $\mathrm{I} 16 \mathrm{~V}(2)$ & $+++(1),-(1)$ & ++ \\
\hline & & V18A (6) & $+++(1),++(1), \pm(1),-(3)$ & $+++(2),++(2), \pm(2)$ \\
\hline SBD & $4 / 4$ & - & +++ & +++ \\
\hline \multicolumn{5}{|l|}{$N$. benthamiana } \\
\hline \multirow[t]{5}{*}{$\mathrm{BSD}^{\mathrm{e}}$} & $15 / 30$ & $(-10)$ & $+(1), \pm(2),-(7)$ & $+++(1),++(3),+(6)$ \\
\hline & & K14R (1) & \pm & +++ \\
\hline & & I16T (1) & +++ & + \\
\hline & & $\mathrm{I16V}(2)$ & +++ & ++ \\
\hline & & V18A (1) & + & +++ \\
\hline $\mathrm{Dc}$ & $0 / 4$ & - & - & - \\
\hline $\mathrm{R}$ & $4 / 4$ & - & +++ & +++ \\
\hline \multicolumn{5}{|l|}{ Arabidopsis thaliana } \\
\hline \multicolumn{5}{|l|}{ Col-0 } \\
\hline BSD & $0 / 8$ & - & - & - \\
\hline $\mathrm{Dc}$ & $0 / 8$ & _- & - & - \\
\hline $\mathrm{R}$ & $8 / 8$ & - & +++ & +++ \\
\hline \multicolumn{5}{|l|}{ Ler } \\
\hline BSD & $1 / 8$ & - & - & + \\
\hline Dc & $0 / 8$ & _- & _- & _- \\
\hline $\mathrm{R}$ & $8 / 8$ & - & +++ & +++ \\
\hline
\end{tabular}

${ }^{\mathrm{a}}$ Infectivity is defined as the number of systemically infected plants/number of inoculated plants.

${ }^{\mathrm{b}}$ Amino acid changes in the N-terminal region of the coat protein are indicated. The minus sign refers to absence of changes and the number in parentheses indicates the number of independent plants in which this specific mutation was observed.

${ }^{\mathrm{c}}$ Symptoms of upper leaves are classified according to their intensity as severe (+++), medium (++), mild (+), very mild ( \pm ), and absent (-). The number of plants displaying a particular symptom is in parentheses.

d Viral accumulation levels, assessed by Western blot or enzyme-linked immunosorbent assay, are classified as high (+++), medium (++), low (+), very low ( \pm ), and null (-). The number of plants displaying a particular viral accumulation level is in parentheses.

${ }^{\mathrm{e}}$ Number of plants displaying a particular viral accumulation level is in parentheses. 
tions and did not undergo further mutations (Tables 2 and 3). There were some exceptions in which the infections were delayed or attenuated. This is the case of the infection of $N$. clevelandii plants inoculated with extracts containing virus progenies with the $\Delta 7-36$ or I16T modifications (Table 2). Attenuated infections were also observed in both Nicotiana spp. infected with virus progenies with D11G and K14R mutations (Table 2 and 3). A second mutation, V18G, was detected in the virus produced in $N$. clevelandii plants infected with a D11Gcontaining virus progeny. In addition, a T19P mutation was observed in one $N$. clevelandii and one $N$. benthamiana plant infected with a K14R-containing virus progeny (Tables 2 and 3 ). The K14R mutation was not stable in the virus accumulating in one $N$. clevelandii plant. R14 was further mutated to Gly, which appeared to cause a notable enhancement of symptoms and viral accumulation in this host (Table 2).

Finally, nonmutated virus progenies from $N$. benthamianainfected plants (Table 1) could not systemically infect $N$. clevelandii plants (Table 2). In contrast, these progenies infected $N$. benthamiana plants, although with a noticeable delay (Table 3). These plants showed mild symptoms and variable levels of virus accumulation at later stages of infection (Table 3 ). Sequencing analysis of the virus progenies showed amino acid changes in the $\mathrm{N}$ terminus of the $\mathrm{CP}$ (I16T and I16F) (Table 3).
These results indicate that, generally, the mutated progenies (except for progenies with D11G and K14R mutations) have high infectivity, accumulated high amounts of virus, and induced severe symptoms. Moreover, all the mutations selected in the initial adaptation of PPV-BSD, except K14R, were stable after one passage in $N$. benthamiana and $N$. clevelandii plants.

\section{Natural variability in the $\mathrm{N}$ terminus of PPV CP.}

An extensive bioinformatic analysis was done in the SharCo database of sequences of natural PPV isolates. The aim of the analysis was to verify whether natural variability already existed at those amino acid positions of the $\mathrm{N}$ terminus of the $\mathrm{CP}$ that mutated during PPV-BSD adaptation to Nicotiana spp.

In all, $583 \mathrm{CP}$ sequences from isolates representing all seven existing PPV strains were retrieved. The natural variability existing in PPV isolates in the amino acid positions of study (positions 11, 14, 16, 18, and 19) is summarized in Table 4. The sequence analysis revealed that the amino acids present in PPV-Dc at these positions (D11, K14, I16, V18, and T19) were highly prevalent in isolates of the $\mathrm{D}$ strain. Some of the amino acids selected in PPV-BSD progenies were common in other PPV strains (R14 in PPV-M, PPV-W, and PPV-EA; T16 in PPV-M, PPV-Rec, and PPV-C; and A18/19 in PPV-W). In addition, most of the amino acids selected in the experimental

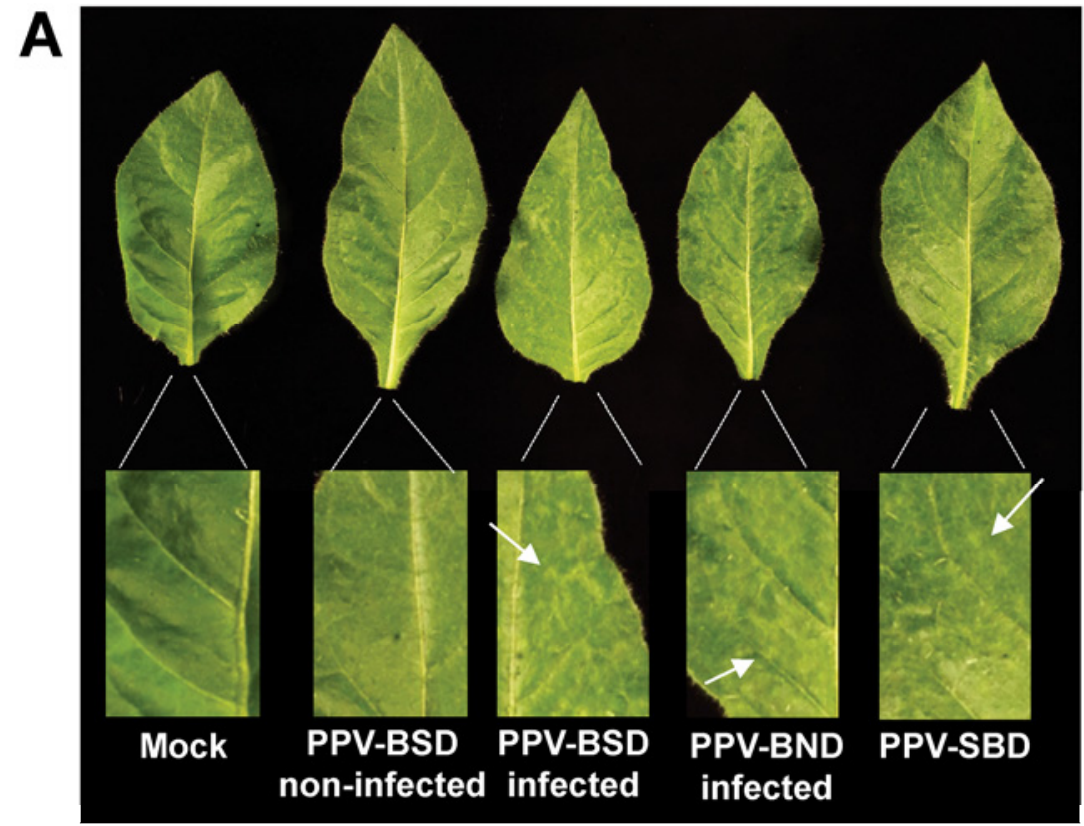

B N. clevelandii infection assay

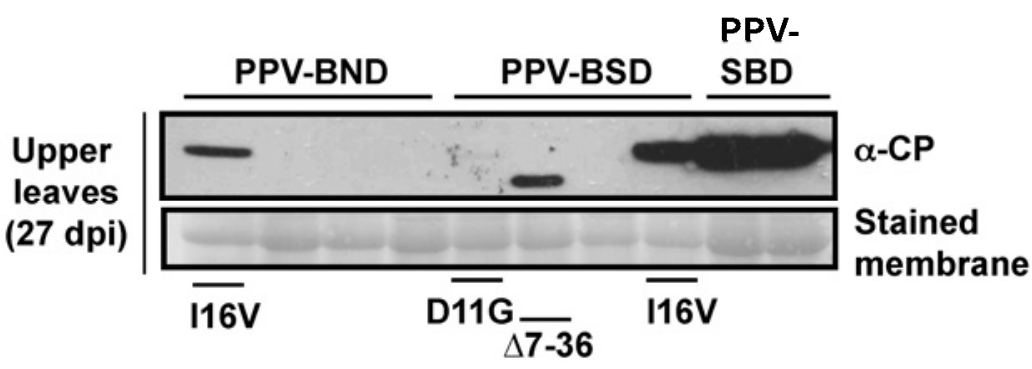

Fig. 2. Infectivity of Plum pox virus (PPV)-D/R hybrids in Nicotiana clevelandii. A, Pictures at 27 days postinoculation (dpi) of upper leaves from plants inoculated with different virus variants. Upper panel, whole leaves. Lower panel, details of leaf sectors in which a few virus-induced chlorotic areas are labeled with white arrows as examples of viral symptoms. Leaf sectors pictures were taken with a 1.7 magnification. B, Western-blot detection of virus coat protein (CP) in upper leaves at $27 \mathrm{dpi}$. The membrane stained with Ponceau red is included as loading control. Mutated residues at the N-terminal region of CP from PPV progenies are shown below the corresponding lane. 
adaptation process (G11, R14, T16, V16, and A19) herein already existed in the $\mathrm{CP}$ of natural PPV isolates of strain D infecting Prunus trees (Table 4). A dN/dS (nonsynonymous/ synonymous substitutions) analysis of the codons 11, 14, 16, 18, and 19 of D-type PPV isolates showed a higher incidence of neutral mutations (Supplementary Table S1). This result indicates that these residues are not under positive selection, and that purifying selection pressure is acting to preserve the wild-type sequence. No deletions were observed within the 30aa region of the $\mathrm{N}$ terminus of the $\mathrm{CP}$ in the sequences of natural PPV isolates deposited in the SharCo database.

\section{Infectivity in $N$. clevelandii of PPV-BSD clones containing} amino acid substitutions in the $\mathbf{N}$ terminus of their $\mathrm{CP}$.

Next, we wanted to further clarify the biological relevance of the amino acid mutations at the $\mathrm{N}$ terminus of the $\mathrm{CP}$ for PPV adaptation to Nicotiana and Prunus spp. For this purpose, we introduced several mutations in PPV-BSD and PPV-Dc cDNA clones because these two variants replicated efficiently in inoculated leaves of Nicotiana and Prunus spp., respectively (Figs. 3B and 4B). PPV-BSD-based mutant clones were used in Nicotiana spp. and PPV-Dc-based mutant clones were used in Prunus spp. The mutant clones contained several of the amino acid changes selected under experimental conditions, which are present (K14R, I16V, and V18A) or absent $(\Delta 7-36$, $\mathrm{K} 14 \mathrm{G}$, I16F, and I16S) in natural PPV isolates. Additionally, the I16M change (resulting from a $\mathrm{T}$ to $\mathrm{G}$ transversion), not selected under experimental conditions and absent in natural PPV isolates, was also introduced. This mutant was selected to further understand how restrictive the host-specific sequence requirements at the $\mathrm{N}$ terminus of PPV $\mathrm{CP}$ are.
PPV-BSD mutant variants described above were inoculated in $N$. clevelandii (Fig. 4). N. clevelandii was selected as the herbaceous host because it was found to be less permissive for PPVBSD infections than $N$. benthamiana (discussed above). Western blot analysis of extracts from the inoculated leaves showed that plants inoculated with wild-type or mutant PPV-BSD variants accumulated high amounts of virus CP. Plants inoculated with most of the mutants accumulated virus $\mathrm{CP}$ similarly to those inoculated with wild-type PPV-BSD or PPV-R (Fig. 4B). The only exceptions were those plants inoculated with PPV-BSD47-36 mutant, which accumulated lower amounts of virus. However, CP levels in these plants were still noticeably higher than those observed in plants inoculated with PPV-Dc (Fig. 4B). All plants inoculated with mutant PPV-BSD clones, except for the K14R mutant, developed systemic disease symptoms (Fig. 4A; Supplementary Table S2). In most of the cases, such as plants inoculated with PPV-R, the infected plants showed systemic symptoms at $10 \mathrm{dpi}$. However, symptoms were delayed and milder in plants infected with PPV-BSD- $\Delta 7-36$ (Fig. 4A). As in previous experiments, the appearance and the intensity of the symptoms of plants infected with PPV-BSD was variable: only two of four plants developed symptoms, of low to medium intensity, which appeared with a 4- to 10-day delay. Western blot analysis at $21 \mathrm{dpi}$ of extracts from upper leaves showed that plants infected with most PPV-BSD mutants, including the variant with the I16M change, accumulated virus $\mathrm{CP}$ to similar levels as plants infected with PPV-R (Fig. 4B). Virus accumulated to lower levels in plants infected with the PPV-BSD- $\Delta 7-36$ mutant and wild-type PPV-BSD chimera, in agreement with the milder symptoms of these plants (Fig. 4). The PPV-BSD-K14R mutant, despite accumulating to high levels in the inoculated

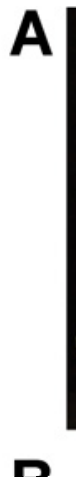

B

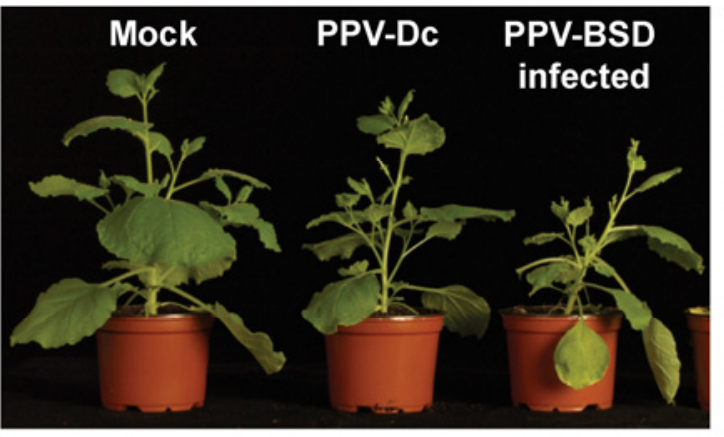

$N$. benthamiana infection assay
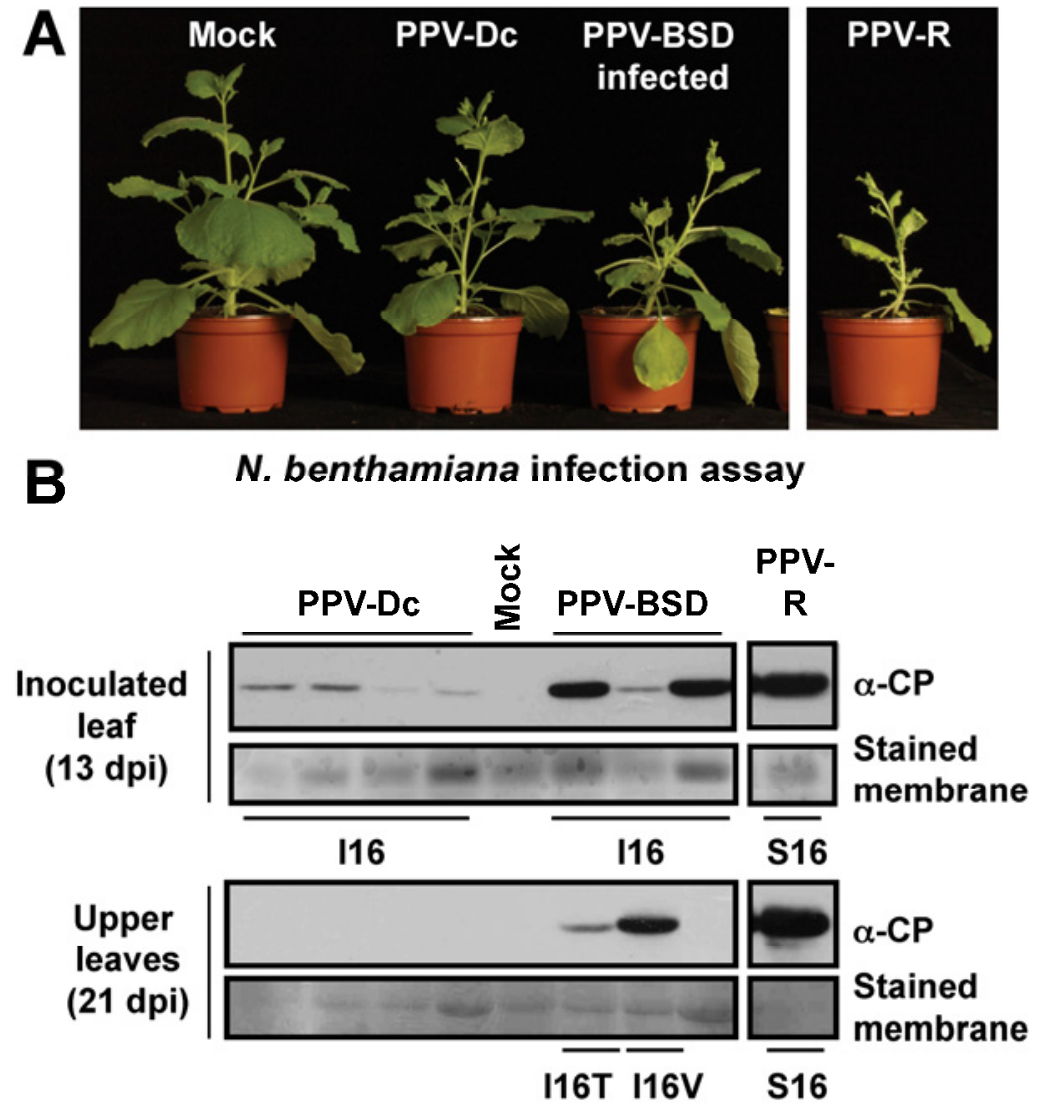

Fig. 3. Infectivity of Plum pox virus (PPV)-BSD chimeras in Nicotiana benthamiana. A, Pictures at 21 days postinoculation (dpi) of plants inoculated with different virus variants. B, Western blot detection of virus coat protein (CP) in inoculated (top) and upper leaves (bottom) at 13 and 21 dpi, respectively. Conserved or mutated residues at the N-terminal region of CP from PPV progenies are shown below the corresponding lane. The membrane stained with Ponceau red is included as loading control. Mutated residues at the N-terminal region of CP from PPV progenies are shown below the corresponding lane. 
tissue, was not able to move systemically because no symptoms or virus $\mathrm{CP}$ were detected in upper noninoculated leaves (Fig. $4 \mathrm{~A}$ and B). Sequencing analysis of the virus progenies from upper leaves showed that, in all cases, the introduced amino acid changes were stable, and no extra mutations were detected in the $\mathrm{N}$ terminus of the $\mathrm{CP}$.

These results confirm that the amino acid changes in the $\mathrm{N}$ terminus of the $\mathrm{CP}$ are important for the infectivity and fitness of the PPV-BSD chimera in herbaceous plants. Although these changes do not increase the accumulation of PPV-BSD in the inoculated leaves, they do affect the systemic spread of the virus.

\section{Infectivity in $P$. persica of PPV-Dc clones containing amino acid substitutions in the $\mathrm{N}$ terminus of their $\mathrm{CP}$.}

As mentioned above, the PPV-BSD chimera is unable to infect $P$. persica because the $5^{\prime}$ end of its genome derives from PPV-R (Fig. 1; Table 1). Thus, to analyze the effect of mutations selected during PPV-BSD adaptation to Nicotiana plants on PPV fitness in Prunus spp., 47-36, K14R, K14G, I16S, I16V, I16F, I16M, and V18A mutations were introduced into the PPVDc cDNA clone. In a first bioassay, PPV-Dc mutant variants were inoculated into $P$. persica GF305 seedlings (Fig. 5). Western blot analysis of extracts from the inoculated leaves showed that seedlings inoculated with PPV-Dc mutants generally accumulated levels of virus $\mathrm{CP}$ similar to those inoculated with wildtype PPV-Dc. However, this was not the case for seedlings inoculated with PPV-Dc-K14G because they accumulated less CP (Fig. 5B). Plants inoculated with mutant clones PPV-Dc-K14R, PPV-Dc-I16S, PPV-Dc-I16V, PPV-Dc-I16F, PPV-Dc-I16M, and PPV-Dc-V18A showed systemic symptoms at 10 dpi, and continued developing symptoms as PPV-Dc. No symptoms were observed in upper leaves of plants inoculated with PPV-Dc- $\Delta 7$ 36 . Very mild symptoms were observed in half of the trees inoculated with PPV-Dc-K14G, and only at a very late time (Fig.
5A; Supplementary Table S3). Western blot analysis at 16 dpi of extracts from upper leaves showed that virus $\mathrm{CP}$ accumulated to similar levels in plants infected with PPV-Dc-K14R, PPV-DcI16V, PPV-Dc-I16S, PPV-Dc-I16F, PPV-Dc-I16M, or PPV-DcV18A compared with plants infected with wild-type PPV-Dc. In contrast, virus $\mathrm{CP}$ did not accumulate in plants inoculated with either PPV-Dc-K14G or PPV-Dc- $\Delta 7-36$ (Fig. 5B). Whereas CP accumulation was observed in plants inoculated with PPV-DcK14G showing mild symptoms at 33 dpi, PPV CP was still not detected in plants inoculated with the PPV-Dc- $\Delta 7-36$ mutant at this time (Supplementary Fig. S2). A second bioassay was carried out to verify the defects in systemic infection caused by the Dc-K14G and Dc- $\Delta 7-36$ mutations (Supplementary Fig. S3). Virus accumulation was highly variable in the inoculated leaves. In contrast to the result of the previous bioassay, leaves inoculated with PPV-Dc-K14G and PPV-Dc- $\Delta 7-36$ clones accumulated higher levels of virus $\mathrm{CP}$ than leaves inoculated with the control viruses. In this second bioassay, plants infected with PPV-Dc-K14G showed symptoms with no delay compared with plants infected with PPV-Dc, PPV-Dc-V18A, or PPV-Dc-K14R. However, both the intensity of the symptoms and the virus accumulation levels of plants infected with PPV-Dc-K14G were notably lower than in plants infected with the control viruses. Plants infected with PPV-Dc- $\Delta 7-36$ did not show symptoms in this experiment either, and virus $\mathrm{CP}$ was not detected by Western blot analysis in upper noninoculated leaves. This result further confirmed the drastic effect of the $\Delta 7-36$ deletion in PPV systemic spread in peach. Sequence analysis of virus progenies from upper leaves indicated that all amino acid changes incorporated were stable even at $40 \mathrm{dpi}$, including the $\mathrm{K} 14 \mathrm{G}$ change that reduced the efficiency of the systemic infection. No extra mutations in the $\mathrm{N}$ terminus of the $\mathrm{CP}$ were selected.

Finally, a competition bioassay was done in GF305 peach seedlings to better understand the effect of the mutations on PPV-Dc fitness in Prunus spp. Based on the data collected in

Table 2. Infectivity and sequence analyses of Plum pox virus (PPV)-BSD variants after one passage in Nicotiana clevelandii

\begin{tabular}{|c|c|c|c|c|c|c|c|}
\hline Mutation & $\begin{array}{c}\text { Progenies } \\
\text { tested }^{\mathrm{a}}\end{array}$ & Infectivity $^{b}$ & $\begin{array}{c}\text { Symptom } \\
\text { appearance }^{c}\end{array}$ & $\begin{array}{l}\text { Symptoms } \\
(21 \text { dpi })^{d}\end{array}$ & $\begin{array}{l}\text { Virus } \\
\text { accumulation }^{\mathrm{e}}\end{array}$ & $\begin{array}{l}\text { Stability of the } \\
\text { mutation }^{\mathrm{f}}\end{array}$ & New mutations ${ }^{\mathrm{g}}$ \\
\hline \multirow[t]{4}{*}{ No } & $\mathrm{Nb}$ & $0 / 3$ & $\ldots$ & $\ldots$ & $\ldots$ & $\ldots$ & $\ldots$ \\
\hline & $\mathrm{Nb}$ & $0 / 3$ & $\ldots$ & $\ldots$ & $\ldots$ & $\ldots$ & $\ldots$ \\
\hline & $\mathrm{Nb}$ & $0 / 3$ & $\ldots$ & $\ldots$ & $\ldots$ & $\ldots$ & $\ldots$ \\
\hline & $\mathrm{Nb}$ & $0 / 3$ & $\ldots$ & $\ldots$ & $\ldots$ & $\ldots$ & $\ldots$ \\
\hline$\Delta 7-36$ & $\mathrm{Nc}$ & $3 / 3$ & 14 & $++(2),+(1)$ & $++(2),+(1)$ & Yes & No \\
\hline D11G & $\mathrm{Nc}$ & $3 / 3$ & 14 & $+++(2),+(1)$ & $+++(2),+(1)$ & Yes & $\mathrm{V} 18 \mathrm{G}^{\mathrm{h}}$ \\
\hline \multirow[t]{2}{*}{ K14R } & $\mathrm{Nb}$ & $2 / 3$ & $11(1)$ & $++(1)$ & $++(1)$ & R14G & No \\
\hline & $\ldots$ & $\ldots$ & $\ldots$ & $-(1)^{\mathrm{i}}$ & $-(1)^{\mathrm{i}}$ & Yes & T19P \\
\hline $\mathrm{I} 16 \mathrm{~S}$ & $\mathrm{Nc}$ & $3 / 3$ & 10 & +++ & +++ & Yes & No \\
\hline \multirow[t]{2}{*}{$\mathrm{I} 16 \mathrm{~T}$} & $\mathrm{Nb}$ & $2 / 3$ & $14(1), 21(1)$ & ++ & + & Yes & No \\
\hline & $\mathrm{Nc}$ & $3 / 3$ & 10 & +++ & +++ & Yes & No \\
\hline \multirow[t]{2}{*}{$\mathrm{I} 16 \mathrm{~V}$} & $\mathrm{Nb}$ & $3 / 3$ & 10 & +++ & +++ & Yes & No \\
\hline & $\mathrm{Nc}$ & $3 / 3$ & $10(1), 14(2)$ & +++ & +++ & Yes & No \\
\hline \multirow[t]{3}{*}{ V18A } & $\mathrm{Nb}$ & $3 / 3$ & 10 & +++ & +++ & Yes & No \\
\hline & $\mathrm{Nc}$ & $3 / 3$ & 14 & +++ & +++ & Yes & No \\
\hline & $\mathrm{Nc}$ & $3 / 3$ & $10(1), 14(2)$ & +++ & +++ & Yes & No \\
\hline
\end{tabular}

${ }^{a}$ Species of the primarily infected plant used as inoculum. $\mathrm{Nb}=N$. benthamiana and $\mathrm{Nc}=N$. clevelandii.

b Infectivity is defined as the number of systemically infected plants/number of inoculated plants.

c Time in days postinoculation (dpi) at which the symptoms were first detected. The number of plants displaying particular behaviors is shown in parentheses.

${ }^{\mathrm{d}}$ Symptoms of upper leaves were scored at $21 \mathrm{dpi}$, and classified according to their intensity as severe (+++), medium (++), mild (+), very mild ( \pm ), and absent (-). The number of plants displaying a particular symptom is in parentheses.

${ }^{\mathrm{e}}$ Virus accumulation was assessed by Western blot analysis at $21 \mathrm{dpi}$, unless otherwise indicated, and classified as high (+++), medium (++), low (+), and not detectable (-). The number of plants displaying a particular virus accumulation level is in parentheses.

$\mathrm{f}$ Conservation or loss of the initial mutation is indicated.

${ }^{g}$ New amino acid changes in residues differing from the original mutated residue are indicated. The number in parentheses indicates the number of independent plants in which this specific mutation was observed.

$\mathrm{h}$ Three plants were analyzed as a pool.

i This plant showed neither symptoms nor viral accumulation in Western blot but was PPV positive by immunocapture reverse-transcription polymerase chain reaction. 
the previous bioassays, clones PPV-Dc-I16V and PPV-DcV18A were selected for the competition experiment because i) both showed similar infectivity in peach and ii) $\mathrm{I} 16 \mathrm{~V}$ and V18A were the most common mutations observed in $N$. benthamiana and $N$. clevelandii, respectively. Pairs PPVDc:PPV-Dc-V18A and PPV-Dc:PPV-Dc-I16V were inoculated in both $1: 1$ and $1: 2$ ratios (Table 5).

Persistence of the competing viruses was analyzed at $30 \mathrm{dpi}$ in extracts from systemically infected leaves. Reversetranscription polymerase chain reaction preceded by immunocapture (IC-RT-PCR) analysis on these extracts was followed by sequencing of the amplified products. PPV-DcV18A and PPV-Dc-I16V showed competitiveness similar to wild-type PPV-Dc in peach because all viruses were maintained in the infected plants at the time of the analysis (Table 5). In a second bioassay where plants infected with PPV-Dc:PPVDc-V18A and PPV-Dc:PPV-Dc-I16V pairs were subjected to vernalization, the mutant variants were again detected to levels similar to wild-type PPV-Dc (data not shown).

These results show that most of the amino acid changes at the $\mathrm{N}$ terminus of the $\mathrm{CP}$ selected to adapt PPV to Nicotiana plants do not noticeably reduce the fitness of PPV-Dc in peach. However, the K14G mutation appears to lead to slower systemic movement whereas the lack of 30 aa of the $\mathrm{CP}(\Delta 7-36)$ renders the virus unable to move systemically.

\section{DISCUSSION}

The $\mathrm{N}$ terminus of the $\mathrm{CP}$ shows high variability in length and sequence among potyviruses (Shukla and Ward 1989), thus prompting the hypothesis that this region could be involved in specific interactions with host factors and adaptation to new hosts. In agreement with this concept, a 15-aa non-aphid-transmissible (NAT) deletion from this region was observed after PPV propagation in herbaceous species (López-Moya et al. 1995; Maiss et al. 1989). Furthermore, recent studies using chimeric viruses indicated that the $\mathrm{N}$ terminus of PPV $\mathrm{CP}$ includes host-specific pathogenicity determinants (Salvador et al. 2008) and also determinants that enable the virus to overcome A. thaliana RTM resistance (Decroocq et al. 2009).

Here, to further dissect such determinants, we used chimeric viruses engineered from two PPV isolates showing high se-

Table 3. Infectivity and sequence analyses of Plum pox virus (PPV)-BSD variants after one passage in Nicotiana benthamiana

\begin{tabular}{|c|c|c|c|c|c|c|c|}
\hline Mutation & $\begin{array}{c}\text { Progenies } \\
\text { tested }^{\mathrm{a}}\end{array}$ & Infectivity $^{b}$ & $\begin{array}{c}\text { Symptom } \\
\text { appearance }^{c}\end{array}$ & $\begin{array}{c}\text { Symptoms at } \\
21 \mathrm{dpi}^{\mathrm{d}}\end{array}$ & Virus accumulation $^{\mathrm{e}}$ & $\begin{array}{l}\text { Stability of the } \\
\text { mutation }^{f}\end{array}$ & $\begin{array}{c}\text { New } \\
\text { mutations }^{\mathrm{g}}\end{array}$ \\
\hline \multirow[t]{4}{*}{ No } & $\mathrm{Nb}$ & $1 / 3$ & 45 & - & $++(56 \mathrm{dpi})$ & $\ldots$ & $\mathrm{I} 16 \mathrm{~T}$ \\
\hline & $\mathrm{Nb}$ & $1 / 3$ & 36 & - & $++(56 \mathrm{dpi})$ & $\ldots$ & $\mathrm{I} 16 \mathrm{~T}$ \\
\hline & $\mathrm{Nb}$ & $2 / 3$ & $36(1), 45(1)$ & - & $+++(56 \mathrm{dpi}),+(56 \mathrm{dpi})$ & $\ldots$ & $\mathrm{I} 16 \mathrm{~F}^{\mathrm{h}}$ \\
\hline & $\mathrm{Nb}$ & $1 / 3$ & 36 & - & $++(56 \mathrm{dpi})$ & $\ldots$ & n.t. \\
\hline$\Delta 7-36$ & $\mathrm{Nc}$ & $3 / 3$ & 10 & +++ & ++ & Yes & No \\
\hline D11G & $\mathrm{Nc}$ & $3 / 3$ & 21 & +++ & ++ & Yes & No \\
\hline \multirow[t]{2}{*}{ K14R } & $\mathrm{Nb}$ & $3 / 3$ & $18(1)$ & $++(1)$ & $+++(1)$ & Yes & T19P \\
\hline & $\ldots$ & $\ldots$ & $\ldots$ & $-(2)^{i}$ & $-(2)^{i}$ & Yes & No \\
\hline I16S & $\mathrm{Nc}$ & $3 / 3$ & 10 & +++ & +++ & Yes & No \\
\hline \multirow[t]{2}{*}{ I16T } & $\mathrm{Nb}$ & $2 / 3$ & 10 & +++ & ++ & Yes & No \\
\hline & $\mathrm{Nc}$ & $3 / 3$ & 10 & +++ & ++ & Yes & No \\
\hline \multirow[t]{2}{*}{$\mathrm{I} 16 \mathrm{~V}$} & $\mathrm{Nb}$ & $3 / 3$ & 10 & +++ & +++ & Yes & No \\
\hline & $\mathrm{Nc}$ & $3 / 3$ & 10 & +++ & +++ & Yes & No \\
\hline \multirow[t]{3}{*}{ V18A } & $\mathrm{Nb}$ & $3 / 3$ & 10 & +++ & +++ & Yes & No \\
\hline & $\mathrm{Nc}$ & $2 / 3$ & 10 & +++ & +++ & Yes & No \\
\hline & $\mathrm{Nc}$ & $3 / 3$ & 10 & +++ & +++ & Yes & No \\
\hline
\end{tabular}

a Species of the primarily infected plant used as inoculum. $\mathrm{Nb}=N$. benthamiana and $\mathrm{Nc}=N$. clevelandii.

${ }^{\mathrm{b}}$ Infectivity is defined as the number of systemically infected plants/number of inoculated plants.

${ }^{c}$ Time in days postinoculation (dpi) at which the symptoms were first detected. The number of plants displaying particular behaviors is shown in parentheses.

d Symptoms of upper leaves were scored at $21 \mathrm{dpi}$, and classified according to their intensity as severe (+++), medium (++), mild (+), very mild $( \pm)$, and absent (-). The number of plants displaying a particular symptom is in parentheses.

${ }^{\mathrm{e}}$ Virus accumulation was assessed by western blot analysis at $21 \mathrm{dpi}$, unless otherwise indicated, and classified as high (+++), medium (++), low (+), and not detectable (-). The number of plants displaying a particular symptom is in parentheses.

${ }^{\mathrm{f}}$ Conservation or loss of the initial mutation is indicated.

${ }^{g}$ New amino acid changes in residues differing from the original mutated residue are indicated. The number in parentheses indicates the number of independent plants in which this specific mutation was observed; n.t. = not tested

$\mathrm{h}$ The two plants were analyzed as a pool.

i Two plants showed neither symptoms nor viral accumulation in Western blot but were PPV positive by immunocapture reverse-transcription polymerase chain reaction.

Table 4. Natural variability in the N-terminal region of the coat protein $(\mathrm{CP})$ of different Plum pox virus (PPV) strains ${ }^{\mathrm{a}}$

\begin{tabular}{|c|c|c|c|c|c|c|c|}
\hline \multirow[b]{3}{*}{$\mathrm{CP}$ amino acid } & \multicolumn{7}{|c|}{ PPV strain, number of sequences } \\
\hline & D & $\mathbf{M}$ & Rec & $\mathbf{T}$ & $\mathbf{C}$ & $\mathbf{W}$ & $\mathbf{E a}$ \\
\hline & 304 & 159 & 102 & 10 & 2 & 4 & 1 \\
\hline 11 & $\mathrm{D}(303) \mathbf{G}$ & $\mathrm{D}(159)$ & $\mathrm{D}(102)$ & $\mathrm{D}(9) \mathrm{N}$ & $\mathrm{D}(2)$ & $\mathrm{D}(4)$ & $\mathrm{D}(1)$ \\
\hline 14 & K (303) R & R (155) K (4) & K (102) & K (10) & $\mathrm{K}(2)$ & $\mathbf{R}(4)$ & $\mathbf{R}(1)$ \\
\hline 16 & I (300) V (3) $\mathbf{T}$ & $\mathbf{T}(159)$ & T (99) A (2) I & I (10) & $\mathbf{T}(2)$ & A (4) & $\mathrm{L}(1)$ \\
\hline 18 & V (304) & V (159) & V (101) A & V (9) G & $\mathrm{T}(2)$ & $\mathbf{A}^{*}(4)$ & $\mathrm{T}(1)$ \\
\hline 19 & $\mathrm{~T}(301) \mathbf{A}(3)$ & $\mathrm{T}(158) \mathrm{N}$ & $\mathrm{T}(100) \mathrm{I}(2)$ & $\mathrm{T}(10)$ & $\mathrm{T}(2)$ & $\mathrm{T}^{*}(4)$ & $\mathrm{T}(1)$ \\
\hline
\end{tabular}

a Sequence information was retrieved from naturally infected-trees from the SharCo database. Number in parentheses indicates the number of isolates in which this specific mutation was observed in the database. Amino acid residues in PPV isolates from the database that were recovered from infectivity assays in the present work are in bold. Asterisk (*) indicates the Winona amino acids 19,20, which align with amino acids 18,19 of other PPV strains in sequence comparisons. 
quence similarity but different host range: PPV-R, which infects herbaceous species, and PPV-D, which is restricted to $P$. persica. In particular, a $3^{\prime}$ end fragment from the PPV genome, which includes the $\mathrm{CP}$ coding sequence, was exchanged for the corresponding fragment of PPV-D in the PPV-R backbone (Fig. 1). Infectivity bioassays showed that the chimeras did not infect $P$. persica (Table 1), indicating that the $3^{\prime}$ end of the PPV-D genome is not sufficient to confer on PPV the ability to infect this host. On the other hand, the chimeras could systemically infect $N$. benthamiana and $N$. clevelandii by replacing or deleting a variety of specific amino acids from the $\mathrm{N}$ terminus of the CP (Figs. 2 and 3). Five substitutions and one deletion in the progeny from $N$. clevelandii-infected plants and four substitutions from $N$. benthamiana-infected plants were identified
(Table 1; Supplementary Fig. S4). In particular, three of the selected mutations were common in both hosts and mapped into the region of the NAT deletion. In addition, mutations introduced in either $N$. clevelandii or $N$. benthamiana facilitated the systemic infection in the converse Nicotiana spp., indicating that requirements at the $\mathrm{N}$ terminus of $\mathrm{CP}$ for PPV systemic infection in different Nicotiana spp. are similar. In contrast, similar mutations allowing for adaptation to A. thaliana were not observed (Table 1), which suggests that PPV infection determinants at the $\mathrm{N}$ terminus of $\mathrm{CP}$ are not specifically conserved in different plant genera.

Most of the mutations introduced in the PPV-BSD chimera allowed an efficient infection and were stable in a subsequent passage (Tables 2 and 3). In contrast, although the D11G and

A

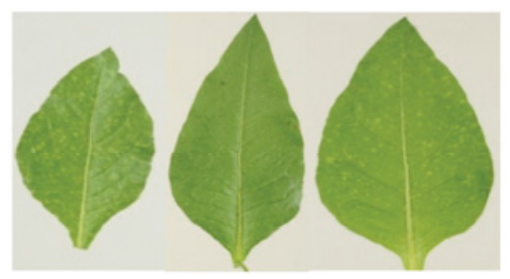

R Dc BSD

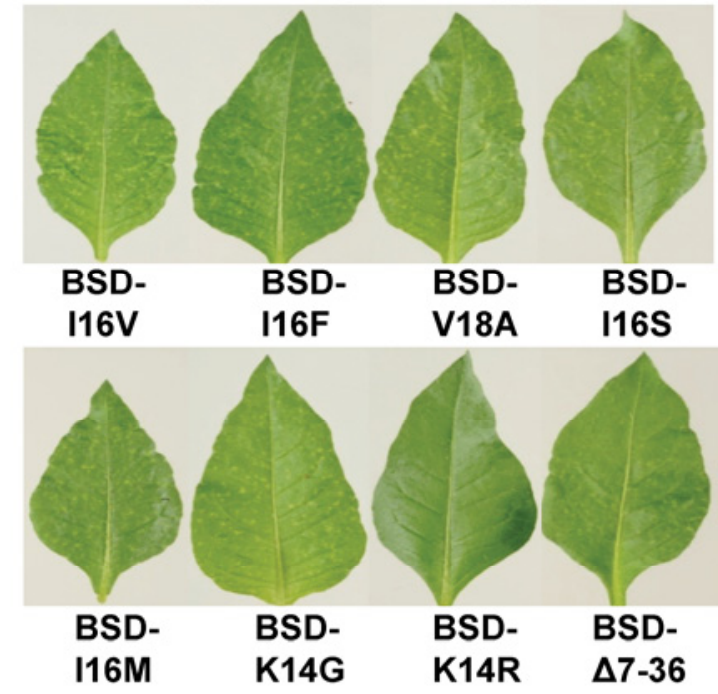

B

N. clevelandii infection assay

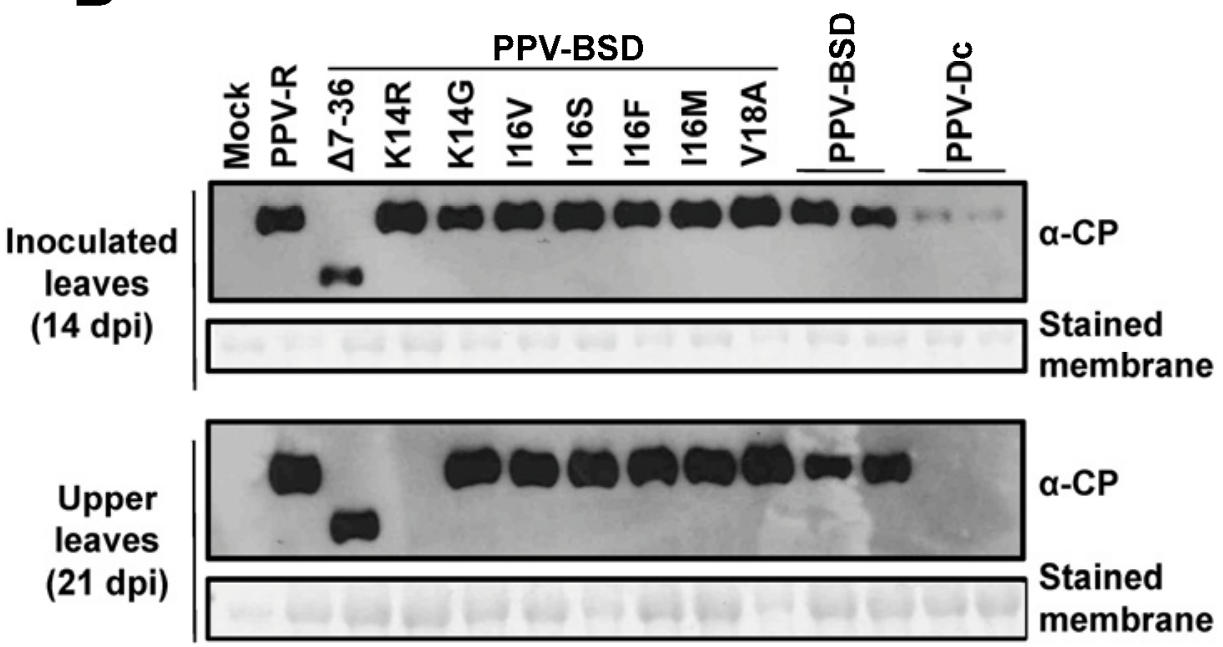

Fig. 4. Infectivity in Nicotiana clevelandii of Plum pox virus (PPV)-BSD hybrids containing mutations at the N-terminal region of PPV coat protein (CP). A, Symptoms observed at 21 days postinoculation (dpi) in upper leaves from plants inoculated with different virus variants. B, Western blot detection of virus $\mathrm{CP}$ in inoculated (top) and upper (bottom) leaves at 14 and $21 \mathrm{dpi}$, respectively. The membrane stained with Ponceau red is included as loading control. 
K14R mutations facilitated PPV-BSD systemic infection, they conferred low fitness because their virus progeny further evolved in the Nicotiana plants (Tables 2 and 3). Thus, in the second round of $N$. clevelandii infections with the virus progeny carrying the K14R mutation, either the residue 14 was further mutated to Gly or a second T19P mutation was selected. It is noteworthy that the T19P mutation, which was not observed in any of the plants infected with the wild-type PPV-BSD chimera,

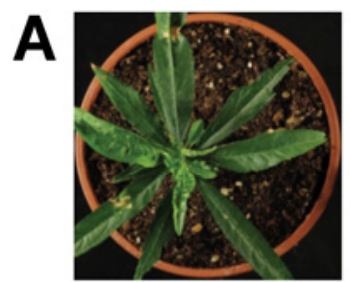

Dc

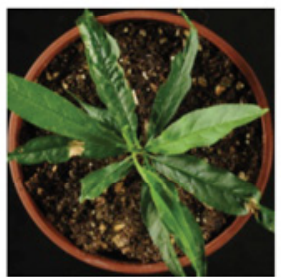

Dc-K14G

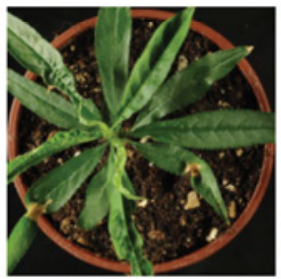

Dc-I16F

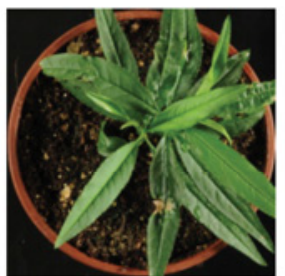

Dc- $\Delta 7-36$

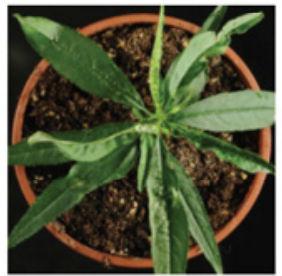

Dc-I16V

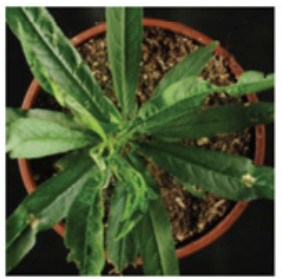

Dc-I16M

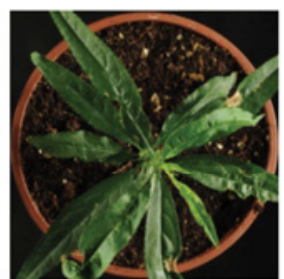

Dc-K14R

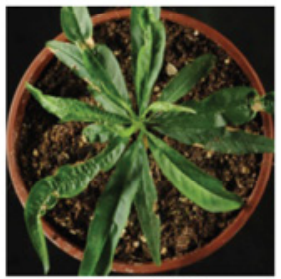

Dc-I16S

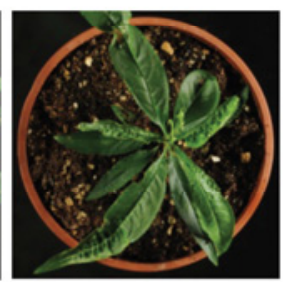

Dc-V18A

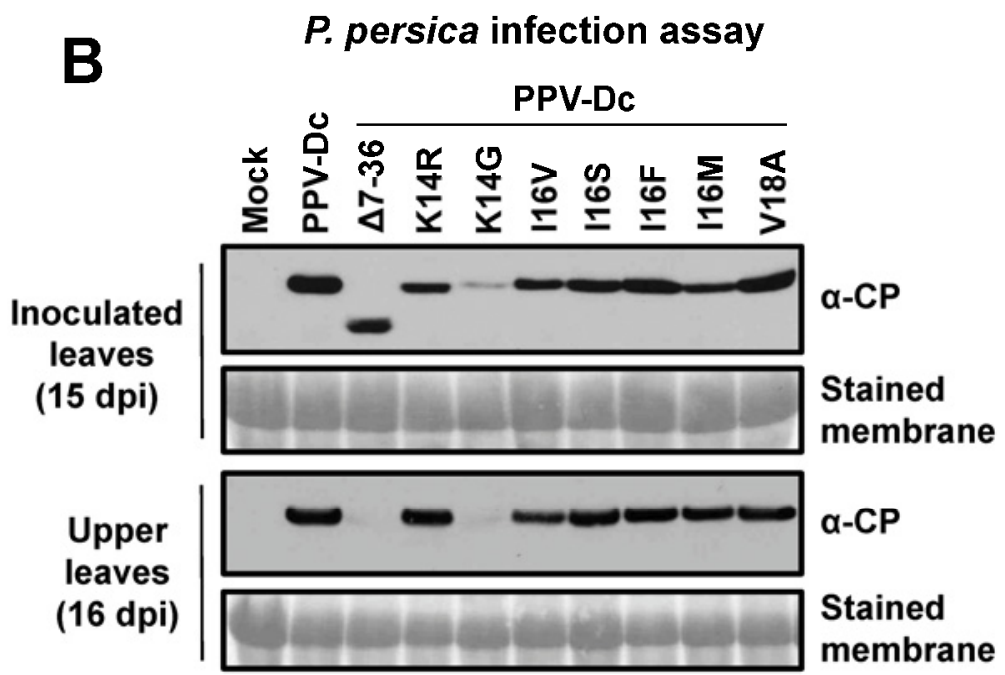

Fig. 5. Infectivity in Prunus persica of Plum pox virus (PPV)-Dc variants containing mutations at the N-terminal region of PPV coat protein (CP). A, Symptoms observed at 30 days postinoculation (dpi) in upper noninoculated leaves from plants inoculated with different virus variants. B, Western blot detection of virus CP in inoculated (top) and upper (bottom) leaves at 15 and $16 \mathrm{dpi}$, respectively. The membrane stained with Ponceau red is included as loading control.

Table 5. Virus detection following co-inoculation experiments with Plum pox virus (PPV) Dc mutants in Prunus persica

\begin{tabular}{|c|c|c|c|c|}
\hline \multirow[b]{2}{*}{ Virus $^{c}$} & \multicolumn{2}{|c|}{ Inoculum 1:1 } & \multicolumn{2}{|c|}{ Inoculum $1: 2^{b}$} \\
\hline & Dc: Dc-V18A & Dc: Dc-I16V & Dc: Dc-V18A & Dc: Dc-I16V \\
\hline Dc & $4 / 4$ & $4 / 4$ & $4 / 4$ & $4 / 4$ \\
\hline Dc-V18A & $4 / 4$ & - & $4 / 4$ & - \\
\hline Dc-I16V & - & $4 / 4$ & - & $4 / 4$ \\
\hline
\end{tabular}

${ }^{a}$ Data shown are the number of plants infected with the indicated virus/total number of inoculated plants.

${ }^{\mathrm{b}}$ Ratio for DNA mixtures in the inocula used for biolistic inoculation.

${ }^{c}$ Recovered virus at 30 days postinoculation. 
was detected together with $\mathrm{K} 14 \mathrm{R}$ in progenies from $N$. clevelandii and $N$. benthamiana (Tables 2 and 3 ). This result suggests a coordinated function of amino acids at positions 14 and 19. A second mutation, V18G, was also introduced together with the D11G mutation after a passage in $N$. clevelandii. Interestingly, although V18A mutations were detected in virus progenies of seven Nicotiana plants directly inoculated with PPV-BSD (Table 1), the V18G mutation was never found alone. This further suggests coordinated actions of different residues of the $\mathrm{N}$ terminus of the CP in PPV adaptation to Nicotiana plants. Collectively, all these results indicate that a variety of mutations at the $\mathrm{N}$ terminus of $\mathrm{CP}$ allow limited or efficient PPV adaptation to Nicotiana hosts.

The selection of a mutation appeared to depend on both the gain of viral fitness and the ease with which it could be generated. The most frequent mutations, I16V, I16T, and V18A, are transitions (ATT $\rightarrow$ GTT, ACT, GTT $\rightarrow$ GCT). These mutations increased the infection efficiency of PPV in $N$. clevelandii when engineered in the cDNA clone of PPV-BSD (Fig. 4). Other mutations at residue $\mathrm{I} 16$ (I16S, I16F, and I16M) supported PPV-BSD infection of $N$. clevelandii with efficiency similar to I16V or I16T mutations (Fig. 4). However, they were selected less frequently (I16F or I16S) or were not selected at all (I16M) (Tables 1-3). This is probably because they are transversions (ATT $\rightarrow$ TTT, ATG, AGT), which are more difficult to generate during genomic replication. The importance in the adaptive process of the ease with which appropriate mutations may occur is even more clearly illustrated in the case of the mutations of the K14 residue. Although the K14G substitution allows for very efficient infection of PPV-BSD in $N$. clevelandii (Fig. 4), it was never detected in plants infected with wild-type PPV-BSD. This is most likely because this substitution requires two mutation events $(\mathrm{AAG} \rightarrow$ GGG). In contrast, a virus variant with a K14R mutation, which derives from a single nucleotide change (AAG $\rightarrow$ AGG), was detected in the first round of infection despite its low fitness in the Nicotiana plants (Table 1).

Most of the mutations favoring PPV adaptation to Nicotiana spp. did not significantly affect virus infectivity in Prunus spp. No significant differences in competitiveness were observed in experiments of coinfection of wild-type PPV-Dc with virus variants, including the most frequent mutations $\mathrm{I} 16 \mathrm{~V}$ and V18A. These results further support the assumption that mutations in the $\mathrm{N}$ terminus of $\mathrm{CP}$ enabling systemic infection in the herbaceous host genus Nicotiana do not necessarily reduce viral fitness in the natural host genus Prunus. In agreement with this conclusion, the analysis of PPV sequences deposited in the SharCo database, obtained from naturally infected-trees, confirmed that most of the mutations selected under experimental conditions in Nicotiana spp. already existed in natural PPV isolates (Table 4). Moreover, a dN/dS analysis of the codons involved in the adaptation to Nicotiana spp. clearly indicated that they are not subjected to positive selection. Thus, these codons may not be contributing significantly to PPV diversification in Prunus hosts.

On the other hand, the dN/dS analysis showed that the residues mutated for adaptation to Nicotiana spp. were under purifying selection in Prunus spp. This suggests that, although several amino acids can competently occupy the positions affected, they are also subjected to important sequence constraints. Thus, the large $\Delta 7-36$ deletion that enables systemic infection of PPV-BSD in Nicotiana spp. (Fig. 4) completely prevented PPV-Dc systemic infection in seedlings of $P$. persica (Fig. 5). Interestingly, the smaller NAT deletion ( $\Delta 13-27)$, which was found to be associated with PPV propagation in herbaceous plants (discussed above), was neither essential for infection in this host nor prevented systemic infection in
Prunus spp. (Salvador et al. 2008). However, the wild-type sequence and the NAT deletion were associated with enhanced fitness in Prunus and Nicotiana spp., respectively (Salvador et al. 2008). A similar situation occurred with PPV variants with different amino acids at position 14. K14 and R14 supported efficient systemic infection of PPV in $P$. persica seedlings but the systemic spread of the virus with G14 was partially compromised (Fig. 5). In contrast, only G14 virus systemically infected Nicotiana plants with efficiency (Fig. 4).

The relevance of the $\mathrm{N}$ terminus of the $\mathrm{CP}$ in potyvirus longdistance movement was previously demonstrated (Andersen and Johansen 1998; Arazi et al. 2001; Dolja et al. 1995; López-Moya and Pirone 1998). Here, the high variability of virus accumulation observed in the inoculated leaves, probably due to the mechanical damage produced in the inoculation procedure, precluded a detailed analysis of local infection. However, our results suggest that those mutations identified in PPV adaptation to $N$. clevelandii affect virus long-distance movement but do not have relevant effects on local infectivity in the inoculated leaves. In this regard, it is important to remark that both the wild-type PPV-BSD chimera and its derivative mutants accumulated to higher levels than PPV-Dc in N. benthamiana-inoculated leaves (Fig. 3). This is in agreement with the fact that the first 6,931 nucleotides of the chimera were derived from the Nicotiana spp.-adapted isolate PPV-R. This is probably the reason that virus variants able to systemically spread emerge when Nicotiana plants are inoculated with PPV-BSD or PPV-BND but not with PPV-Dc.

Two models could explain the mechanisms by which the selected mutations in the N terminus of PPV CP affect systemic infection in Nicotiana and Prunus plants. In the first scenario, a specific interaction between a host movement factor (MF) and the $\mathrm{N}$ terminus of PPV $\mathrm{CP}$ is required for the systemic movement of the virus (Fig. 6A). The host factor of Nicotiana spp. appears to be quite permissive. It interacts with a large number of variants, including a deletion mutant, but is unable to functionally interact with the CP of PPV-D. Interestingly, the specific host factor of Prunus spp. is also permissive to most of these selected variants but will not fit with the truncated CP $\Delta 7-36$ (Fig. 6A). Whereas this model involving a large number of gainof-function mutants cannot be ruled out, a more appealing model is that Nicotiana hosts might express a defense factor (DF). This DF could interact with the $\mathrm{N}$ terminus of PPV-D CP, preventing virus systemic movement by disturbing a productive interaction of the viral protein with an MF of the plant (Fig. 6B). Specific changes at the $\mathrm{N}$ terminus of the $\mathrm{CP}$ would disrupt its interaction with the DF without causing a drastic disturbance of the interaction with the MF, resulting in systemic movement of the virus. In the absence of a similar DF in Prunus spp., the mutants selected in Nicotiana spp. would still be functional in these plants although, in many cases, with some lower efficiency when the mutation affects the interaction with the MF of Prunus spp. However, a drastic mutation like the large $\Delta 7-36$ deletion could more severely affect the CP-MF interaction in Prunus spp. and prevent virus movement (Fig. 6B).

More broadly, the results reported here provide direct evidence supporting the idea that adaptation to new hosts, regardless of the mechanism, results in diversification of the viral population. This diversification could potentiate further adaptive evolution, highlighting the evolutionary power of host shifts.

In summary, the fine dissection of PPV pathogenicity determinants presented here clearly assesses a key role of a few specific amino acids at the $\mathrm{N}$ terminus of the $\mathrm{CP}$ in PPV adaptation to different host species. However, the subset of host factors, enhancers or inhibitors of the infection, that specifically interact with the viral $\mathrm{CP}$ in a potyvirus infection still remain to be elucidated. 


\section{MATERIALS AND METHODS}

Plant hosts.

Viral infectivity assays were performed in A. thaliana, $N$. benthamiana, N. clevelandii, and P. persica (peach) 'GF305' plants. All plants were grown in a greenhouse maintained at 16 $\mathrm{h}$ of light with supplemental lighting and a temperature range of 19 to $23^{\circ} \mathrm{C}$.

Construction of full-length hybrid clones and mutants.

The full-length cDNA clones pICPPV-Dc (Dc) (Salvador et al. 2008), pICPPV-NK-GFP (PPV-R) (Fernández-Fernández et al. 2001), and the PPV-D/R hybrid pICPPV-SBD (SBD) (Salvador et al. 2008) were previously described. The two chimeras pICPPV-BSD (BSD) and pICPPV-BND (BND) were constructed by exchanging fragments using the restriction enzymes indicated in Figure 1.
For the generation of BSD chimeras carrying K14R, K14G, I16S, and I16V mutations at the N-terminal region of the $\mathrm{CP}$, an IC-RT-PCR product amplified with primers number 272 (5'-TTTAACGATGATGGTG-3') and number 55 (5'-CTATGC ACCAAACC $\left.-3^{\prime}\right)$ from the BSD virus progeny carrying the respective mutation and digested with $\mathrm{BpiI} / \mathrm{Sac} \mathrm{I}$ was ligated with two fragments generated from the pICPPV-BSD plasmid digested with BamHI/BpiI and BamHI/SacI, respectively. The BSD-I16M mutant was similarly generated but the I16M change in the PCR product was created by site-directed mutagenesis because no virus progeny carrying the specific mutation was naturally selected. First, two different PCR amplifications were done using pIC-PPV-BSD as a template and primers number 80 (5'-TTGGGTTCTTGAACAAGC-3') and number CP-I16M-Rev (5'-AGT AAC TAC CAT CGG CTT GCC-3'), and number CP-I16M-For (5'-GGC AAG CCG ATG GTA
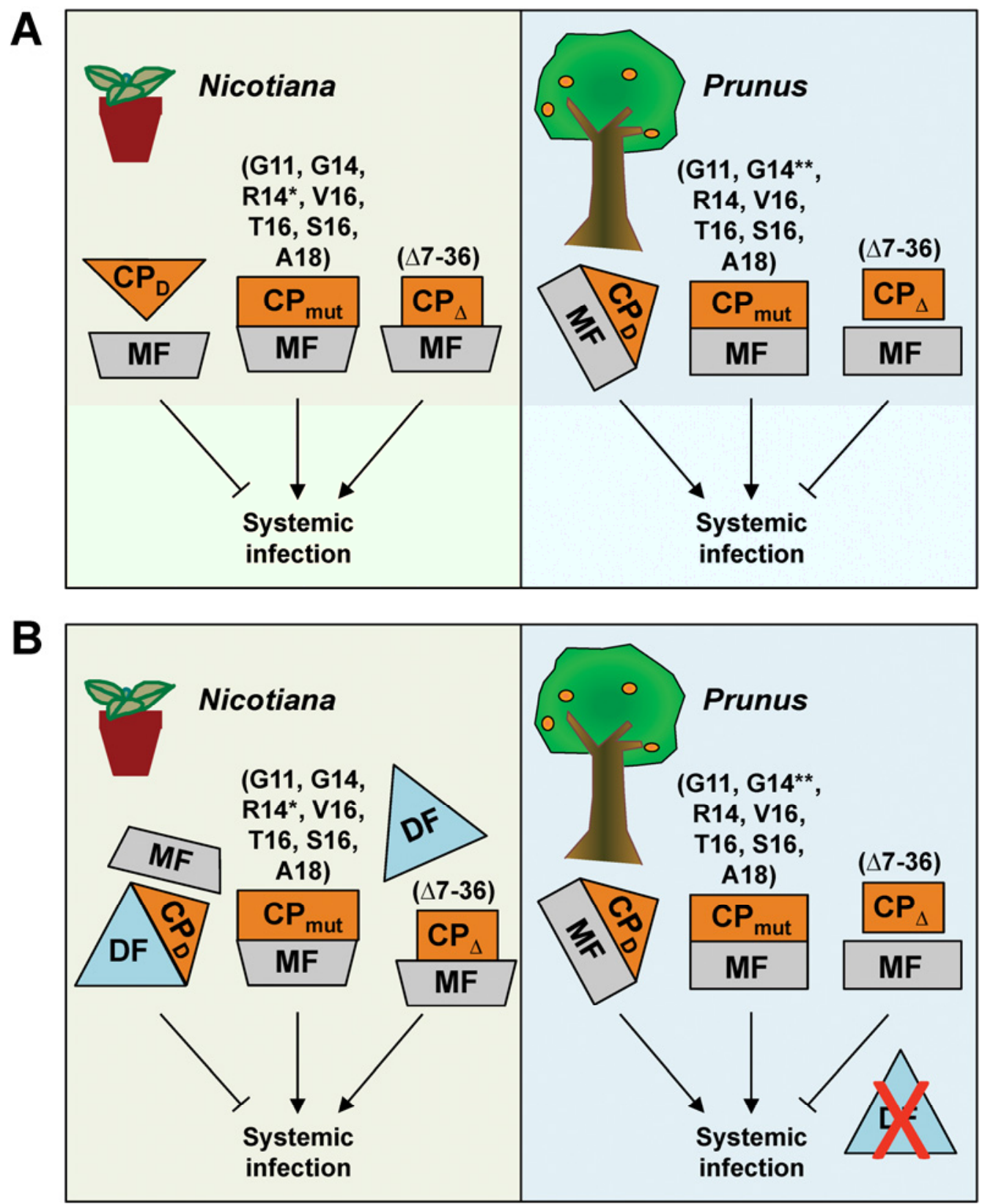

Fig. 6. Models explaining the infectivity of the Plum pox virus (PPV)-D/R hybrids containing mutations in the coat protein (CP). A, Viral movement requires a compatible interaction between the $\mathrm{CP}$ and a movement factor (MF). B, Virus movement is preserved when the $\mathrm{CP}$ escapes the interaction with a host defense factor (DF). Asterisks: * indicates that PPV with R14 only infects systemically Nicotiana benthamiana but not $N$. clevelandii; ** indicates that systemic infection of PPV with G14 is reduced when compared with the rest of the mutants listed in parentheses. 
GTT ACT G-3') and number 55ext (5'-CATTCTCTATGCA CCAAACC-3') respectively. These were followed by a second PCR with primers number 80 and 55ext, in which the products from the first two PCR assays were included as templates. pIC-PPV-BSD-I16F, pIC-PPV-BSD-V18A, and pIC-PPVBSD- $\triangle 7-36$ constructs were generated by ligating the $\mathrm{BamHI} /$ SacI fragment from the respective pIC-PPV-Dc-I16F, pICPPV-Dc-V18A, and pIC-PPV-Dc- $\Delta 7-36$ constructs with the BamHI/SacI-digested pIC-PPV-BSD plasmid.

Likewise, for the generation of pIC-PPV-Dc-K14R, pICPPV-Dc-K14G, pIC-PPV-Dc-I16S, pIC-PPV-Dc-I16F, and pIC-PPV-Dc-V18A constructs, an IC-RT-PCR product amplified with primers number 272 and 55 from the PPV-BSD virus progeny carrying the respective mutation and digested with $\mathrm{Bpi} / \mathrm{Sac}$ I was ligated with two fragments, generated from $\mathrm{pIC}$ PPV-Dc plasmid digested with BamHI/BpiI and BamHI/SacI, respectively. The pIC-PPV-Dc-I16M construct was generated in a similar way but the I16M change in the PCR product was created by site-directed mutagenesis, as described above. The pIC-PPV-Dc-I16V construct was generated by ligating the BamHI/SacI fragment from pIC-PPV-BSD-I16V with BamHI/ SacI digested pIC-PPV-Dc plasmid. pIC-PPV-Dc- $\Delta 7-36$ was generated by ligating a PCR product amplified with primers number 921 (5'-AGGAGCTCTACGTCACTGATCC-3') and number 55 from the PPV-BSD virus progeny carrying the respective deletion, and digested with $B s t \mathrm{XI} / \mathrm{Sac} \mathrm{I}$, with the $B s t \mathrm{XI} / S a c \mathrm{I}$-digested vector $\mathrm{pIC}-\mathrm{PPV}-\mathrm{Dc}$.

\section{Biolistic and manual inoculation.}

A. thaliana, $N$. benthamiana, and $N$. clevelandii plants and P. persica GF305 seedlings were biolistically inoculated using the Helios Gene Gun System (Bio-Rad Laboratories, Hercules, CA, U.S.A.). Microcarrier cartridges were prepared from two different clones per construct, with $1.0 \mu \mathrm{m}$ gold particles coated with the different plasmids at a DNA loading ratio of 2 $\mu \mathrm{g} / \mathrm{mg}$ of gold and a microcarrier loading of $0.5 \mathrm{mg} / \mathrm{shooting}$. Helium pressures of 7.5 and 10 bar were used for inoculating herbaceous hosts (A. thaliana, N. benthamiana, and N. clevelandii) and peach GF305 seedlings, respectively. Each cartridge was shot twice onto two leaves of each plant and, for each plant, one or two cartridges were administered for herbaceous and GF305 hosts, respectively. Usually, eight plants per construct (four per clone) were inoculated in each experiment.

For manual inoculation (second passage) of the virus progeny with or without mutations at the $\mathrm{N}$ terminus of the $\mathrm{CP}$, upper leaves from infected $N$. clevelandii or $N$. benthamiana plants were ground with $5 \mathrm{mM}$ sodium phosphate $(\mathrm{pH} 7.5)$ with an ice-cold pestle (1 $\mathrm{g}$ in $2 \mathrm{ml})$. Extracts were centrifuged to eliminate tissue fragments. For each extract, two leaves were dusted with Carborundum and inoculated with a total of $15 \mu \mathrm{l}$ of extract. Usually, each virus progeny was inoculated onto three $N$. clevelandii and $N$. benthamiana plants. Virus infection was monitored by the observation of symptoms.

\section{ELISA and Western blot assays.}

Inoculated or systemically infected leaves were harvested, ground to a fine powder under liquid nitrogen, and stored at $-80^{\circ} \mathrm{C}$ until use. Control samples corresponding to noninfected leaves were taken from equivalent areas. The tissue was homogenized in $5 \mathrm{mM}$ sodium phosphate buffer (SPB), $\mathrm{pH} 7.5$, ( $1 \mathrm{~g}$ in $2 \mathrm{ml}$ ) and virus accumulation was assessed using doubleantibody sandwich indirect ELISA with a REALISA kit (Durviz, Valencia, Spain) as previously described (Salvador et al. 2008). For Western blot analysis, plant extracts were further diluted in a ratio of $1: 1$ in disruption buffer $(150 \mathrm{mM}$ Tris- $\mathrm{HCl}$ [pH 7.5], $6 \mathrm{M}$ urea, 2\% sodium dodecyl sulfate, and 5\% ßmercaptoethanol). Samples were boiled for $10 \mathrm{~min}$, and cell debris were removed by centrifugation at $18,000 \times g$ at $4^{\circ} \mathrm{C}$ for $10 \mathrm{~min}$. Supernatants were resolved on sodium dodecyl sulfatepolyacrylamide gels (12\% acrylamide), electroblotted to a nitrocellulose membrane, and subjected to Western blot analysis. Virus CP was detected using anti-CP rabbit serum as primary antibody, and horseradish peroxidase-conjugated goat anti-rabbit immunoglobulin G (IgG) (Jackson, West Grove, PA, U.S.A.) as secondary reagent. The immunostained proteins were visualized by enhanced chemiluminiscence detection with a LifeABlot kit (Euroclone, Milano, Italy). Ponceau red staining was used to check the global protein content of the samples.

\section{IC-RT-PCR and DNA sequencing.}

Leaves from infected A. thaliana, $N$. benthamiana, $N$. clevelandii, and $P$. persica GF305 plants were homogenized in $5 \mathrm{mM}$

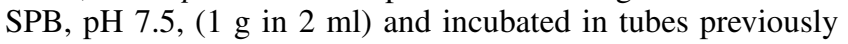
coated with anti-PPV IgG overnight at $4^{\circ} \mathrm{C}$. The incubation was followed by two washing steps with phosphate-buffered saline (PBS)-Tween buffer (16 mM PBS, $0.1 \mathrm{M} \mathrm{NaCl}$, and Tween 20 at $0.5 \mathrm{~g} /$ liter; $\mathrm{pH}$ 7.2). RT-PCR was done using the Titan kit (Roche Molecular Biochemical, Branchburg, NJ, U.S.A.) with primers number 80 and 82 (5'-TGGCACTGTAA AAGTTGG-3'), targeting the $5^{\prime}$ end of the $\mathrm{CP}$ coding sequence. For further sequence analysis, PCR fragments were purified using a MinElute PCR purification kit (Qiagen, Hilden, Germany) and sequenced by Macrogen (Seoul, Korea). IC-RT-PCR and subsequent sequencing analysis was done once for each individual plant unless otherwise stated.

\section{Sequence analysis.}

PPV sequences from different isolates were obtained from the SharCo database. Only those SharCo sequences obtained from naturally infected trees were used in the analyses. A phylogenetic analysis of the PPV sequences followed by a selection analysis was done. Redundant sequences were deleted from the dataset according to the workflow of Moury and Simon (2011). The phylogenetic tree was obtained using MEGA5 software (Tamura et al. 2011), and the best substitution model by Modeltest, maximum likelihood, and neighbor-joining methods were used. The inferred tree was used to find the codon sites under positive selection $(\mathrm{dN} / \mathrm{dS}>1)$. For this purpose, HyPhy software (Pond et al. 2005) was used. In particular, single-likelihood ancestor counting, fixed-effects likelihood, and random-effects likelihood methods were applied.

\section{ACKNOWLEDGMENTS}

This work was supported by grants BIO2010-18541 from Spanish MEC (Ministry of Economy and Competitiveness), SAL/0185/2006 from Comunidad de Madrid, and KBBE-204429 from the European Union. B. Salvador was a recipient of an FPI (Training of Research Personnel) fellowship from MEC. A. Carbonell and V. I. Maliogka contributed equally to this work. We thank N. Fahlgren (Donald Danforth Plant Science Center) for the review of the English text and B. García and E. Dominguez for technical assistance.

\section{LITERATURE CITED}

Abdul-Razzak, A., Guiraud, T., Peypelut, M., Walter, J., Houvenaghel, M. C., Candresse, T., Gall, O., and German-Retana, S. 2009. Involvement of the cylindrical inclusion (CI) protein in the overcoming of an eIF4Emediated resistance against Lettuce mosaic potyvirus. Mol. Plant Pathol. 10:109-113.

Andersen, K., and Johansen, I. E. 1998. A single conserved amino acid in the coat protein gene of pea seed-borne mosaic potyvirus modulates the ability of the virus to move systemically in Chenopodium quinoa. Virology 241:304-311.

Arazi, T., Shiboleth, Y. M., and Gal-On, A. 2001. A nonviral peptide can replace the entire $\mathrm{N}$ terminus of zucchini yellow mosaic potyvirus coat protein and permits viral systemic infection. J. Virol. 75:6329-6336. 
Biebricher, C. K., and Eigen, M. 2006. What is a quasispecies? Curr. Top. Microbiol. Immunol. 299:1-31.

Carbonell, A., Dujovny, G., Garcia, J. A., and Valli, A. 2012. The Cucumber vein yellowing virus silencing suppressor $\mathrm{P} 1 \mathrm{~b}$ can functionally replace HCPro in Plum pox virus infection in a host-specific manner. Mol. Plant-Microbe Interact. 25:151-164.

Chen, K. C., Chiang, C. H., Raja, J. A., Liu, F. L., Tai, C. H., and Yeh, S. D. 2008. A single amino acid of NIapro of Papaya ringspot virus determines host specificity for infection of papaya. Mol. Plant-Microbe Interact. 21:1046-1057.

Chung, B. Y., Miller, W. A., Atkins, J. F., and Firth, A. E. 2008. An overlapping essential gene in the Potyviridae. Proc. Natl. Acad. Sci. U.S.A. 105:5897-5902.

Dallot, S., Quiot-Douine, L., Sáenz, P., Cervera, M. T., García, J. A., and Quiot, J. B. 2001. Identification of Plum pox virus determinants implicated in specific interactions with different Prunus spp. Phytopathology 91:159-164

Decroocq, V., Salvador, B., Sicard, O., Glasa, M., Cosson, P., SvanellaDumas, L., Revers, F., García, J. A., and Candresse, T. 2009. The determinant of potyvirus ability to overcome the RTM resistance of Arabidopsis thaliana maps to the N-terminal region of the coat protein. Mol. Plant-Microbe Interact. 22:1302-1311.

Dolja, V. V., Haldeman-Cahill, R., Montgomery, A. E., Vandenbosch, K. A., and Carrington, J. C. 1995. Capsid protein determinants involved in cell-to-cell and long distance movement of tobacco etch potyvirus. Virology 206:1007-1016.

Domingo, E., and Holland, J. J. 1997. RNA virus mutations and fitness for survival. Annu. Rev. Microbiol. 51:151-178.

Eigen, M. 1996. On the nature of virus quasispecies. Trends Microbiol 4:216-218.

Elena, S. F., Bedhomme, S., Carrasco, P., Cuevas, J. M., de la Iglesia, F., Lafforgue, G., Lalic, J., Prosper, A., Tromas, N., and Zwart, M. P. 2011. The evolutionary genetics of emerging plant RNA viruses. Mol. PlantMicrobe Interact. 24:287-293.

Faurez, F., Baldwin, T., Tribodet, M., and Jacquot, E. 2012. Identification of new Potato virus $Y$ (PVY) molecular determinants for the induction of vein necrosis in tobacco. Mol. Plant Pathol. 13:948-959.

Fellers, J. P., Tremblay, D., Handest, M. F., and Lommel, S. A. 2002. The Potato virus $Y \mathrm{M}^{\mathrm{S}} \mathrm{N}^{\mathrm{R}}$ Nlb-replicase is the elicitor of a veinal necrosishypersensitive response in root knot nematode resistant tobacco. Mol. Plant Pathol. 3:145-152.

Fernández-Fernández, M. R., Mouriño, M., Rivera, J., Rodríguez, F., Plana-Durán, J., and García, J. A. 2001. Protection of rabbits against rabbit hemorrhagic disease virus by immunization with the VP60 protein expressed in plants with a potyvirus-based vector. Virology 280:283-291

Gallois, J. L., Charron, C., Sanchez, F., Pagny, G., Houvenaghel, M. C., Moretti, A., Ponz, F., Revers, F., Caranta, C., and German-Retana, S. 2010. Single amino acid changes in the Turnip mosaic virus viral genome-linked protein ( $\mathrm{VPg}$ ) confer virulence towards Arabidopsis thaliana mutants knocked out for eukaryotic initiation factors eIF(iso)4E and eIF(iso)4G. J. Gen. Virol. 91:288-293.

García, J. A., and Cambra, M. 2007. Plum pox virus and sharka disease. Plant Viruses 1:69-79.

Hjulsager, C. K., Olsen, B. S., Jensen, D. M., Cordea, M. I., Krath, B. N., Johansen, I. E., and Lund, O. S. 2006. Multiple determinants in the coding region of Pea seed-borne mosaic virus $\mathrm{P} 3$ are involved in virulence against sbm-2 resistance. Virology 355:52-61.

Jenner, C. E., Wang, X., Tomimura, K., Ohshima, K., Ponz, F., and Walsh, J. A. 2003. The dual role of the potyvirus P3 protein of Turnip mosaic virus as a symptom and avirulence determinant in brassicas. Mol. PlantMicrobe Interact. 16:777-784.

Jones, R. A. 2009. Plant virus emergence and evolution: Origins, new encounter scenarios, factors driving emergence, effects of changing world conditions, and prospects for control. Virus Res. 141:113-130.

Keller, K. E., Johansen, I. E., Martin, R. R., and Hampton, R. O. 1998. Potyvirus genome-linked protein (VPg) determines Pea seed-borne mosaic virus pathotype-specific virulence in Pisum sativum. Mol. PlantMicrobe Interact. 11:124-130.

López-Moya, J. J., and Pirone, T. P. 1998. Charge changes near the N terminus of the coat protein of two potyviruses affect virus movement. J. Gen. Virol. 79:161-165.

López-Moya, J. J., Canto, T., Díaz-Ruíz, J. R., and López-Abella, D. 1995. Transmission by aphids of a naturally non-transmissible Plum pox virus isolate with the aid of Potato virus $Y$ helper component. J. Gen. Virol. 76:2293-2297.

López-Moya, J. J., Valli, A., and García, J. A. 2009. Potyviridae. In: Encyclopedia of Life Sciences (ELS). John Wiley \& Sons, Ltd., Chichester, U.K.

Maiss, E., Timpe, U., Brisske, A., Jelkmann, W., Casper, R., Himmler, G.,
Mattanovich, D., and Katinger, H. W. 1989. The complete nucleotide sequence of Plum pox virus RNA. J. Gen. Virol. 70:513-524.

Maliogka, V. I., Salvador, B., Carbonell, A., Sáenz, P., León, D. S. Oliveros, J. C., Delgadillo, M. O., García, J. A., and Simón-Mateo, C. 2012. Virus variants with differences in the P1 protein coexist in a Plum pox virus population and display particular host-dependent pathogenicity features. Mol. Plant Pathol. 13:877-886.

Malpica, J. M., Fraile, A., Moreno, I., Obies, C. I., Drake, J. W., and GarcíaArenal, F. 2002. The rate and character of spontaneous mutation in an RNA virus. Genetics 162:1505-1511.

Masuta, C., Nishimura, M., Morishita, H., and Hataya, T. 1999. A single amino acid change in viral genome-associated protein of Potato virus $Y$ correlates with resistance breaking in 'Virgin A Mutant' tobacco. Phytopathology 89:118-123.

Moury, B., and Simon, V. 2011. dN/dS-based methods detect positive selection linked to trade-offs between different fitness traits in the coat protein of Potato virus Y. Mol. Biol. Evol. 28:2707-2717.

Moury, B., Morel, C., Johansen, E., Guilbaud, L., Souche, S., Ayme, V., Caranta, C., Palloix, A., and Jacquemond, M. 2004. Mutations in Potato virus $Y$ genome-linked protein determine virulence toward recessive resistances in Capsicum annuum and Lycopersicon hirsutum. Mol. Plant-Microbe Interact. 17:322-329.

Moury, B., Caromel, B., Johansen, E., Simon, V., Chauvin, L., Jacquot, E. Kerlan, C., and Lefebvre, V. 2011. The helper component proteinase cistron of Potato virus $Y$ induces hypersensitivity and resistance in potato genotypes carrying dominant resistance genes on chromosome IV. Mol. Plant-Microbe Interact. 24:787-797.

Nagyova, A., Kamencayova, M., Glasa, M., and Subr, Z.W. 2012. The 3'proximal part of the Plum pox virus $\mathrm{P} 1$ gene determinates the symptom expression in two herbaceous host plants. Virus Genes 44:505-512.

Nakahara, K. S., Shimada, R., Choi, S.-H., Yamamoto, H., Shao, J., and Uyeda, I. 2010. Involvement of the P1 cistron in overcoming eIF4Emediated recessive resistance against Clover yellow vein virus in pea. Mol. Plant-Microbe Interact. 23:1460-1469.

Pond, S. L., Frost, S. D., and Muse, S. V. 2005. HyPhy: Hypothesis testing using phylogenies. Bioinformatics 21:676-679.

Revers, F., Le Gall, O., Candresse, T., and Maule, A. J. 1999. New advances in understanding the molecular biology of plant/potyvirus interactions. Mol. Plant-Microbe Interact. 12:367-376.

Rodríguez-Cerezo, E., Klein, P. G., and Shaw, J. G. 1991. A determinant of disease symptom severity is located in the $3^{\prime}$-terminal noncoding region of the RNA of a plant virus. Proc. Natl. Acad. Sci. U.S.A. 88:9863-9867.

Sáenz, P., Cervera, M. T., Dallot, S., Quiot, L., Quiot, J. B., Riechmann, J. L., and García, J. A. 2000. Identification of a pathogenicity determinant of Plum pox virus in the sequence encoding the C-terminal region of protein P3+6K1. J. Gen. Virol. 81:557-566.

Sáenz, P., Quiot, L., Quiot, J. B., Candresse, T., and García, J. A. 2001. Pathogenicity determinants in the complex virus population of a Plum pox virus isolate. Mol. Plant-Microbe Interact. 14:278-287.

Salvador, B. 2008. Pathogenicity and Host Range Determinants in Plum pox virus Infection: A Role for P1 Protein. Universidad Autónoma de Madrid, Madrid.

Salvador, B., García, J. A., and Simón-Mateo, C. 2006. Causal agent of sharka disease: Plum pox virus genome and function of gene products. EPPO Bull. 36:229-238.

Salvador, B., Delgadillo, M. O., Sáenz, P., García, J. A., and Simón-Mateo, C. 2008. Identification of Plum pox virus pathogenicity determinants in herbaceous and woody hosts. Mol. Plant-Microbe Interact. 21:20-29.

Scholthof, K. B., Adkins, S., Czosnek, H., Palukaitis, P., Jacquot, E., Hohn, T., Hohn, B., Saunders, K., Candresse, T., Ahlquist, P., Hemenway, C., and Foster, G. D. 2011. Top 10 plant viruses in molecular plant pathology. Mol. Plant Pathol. 12:938-954

Seo, J. K., Lee, S. H., and Kim, K. H. 2009. Strain-specific cylindrical inclusion protein of Soybean mosaic virus elicits extreme resistance and a lethal systemic hypersensitive response in two resistant soybean cultivars. Mol. Plant-Microbe Interact. 22:1151-1159.

Shukla, D. D., and Ward, C. W. 1989. Structure of potyvirus coat proteins and its application in the taxonomy of the potyvirus group. Adv. Virus Res. 36:273-314.

Simón-Buela, L., Guo, H. S., and García, J. A. 1997. Long sequences in the $5^{\prime}$ noncoding region of plum pox virus are not necessary for viral infectivity but contribute to viral competitiveness and pathogenesis. Virology 233:157-162.

Sochor, J., Babula, P., Adam, V., Krska, B., and Kizek, R. 2012. Sharka: The past, the present and the future. Viruses 4:2853-2901.

Spetz, C., and Valkonen, J. P. T. 2004. Potyviral 6K2 protein long-distance movement and symptom-induction functions are independent and hostspecific. Mol. Plant-Microbe Interact. 17:502-510.

Suehiro, N., Natsuaki, T., Watanabe, T., and Okuda, S. 2004. An importan 
determinant of the ability of Turnip mosaic virus to infect Brassica spp. and/or Raphanus sativus is in its P3 protein. J. Gen. Virol. 85:2087-2098.

Tamura, K., Peterson, D., Peterson, N., Stecher, G., Nei, M., and Kumar,

S. 2011. MEGA5: Molecular evolutionary genetics analysis using maximum likelihood, evolutionary distance, and maximum parsimony methods. Mol. Biol. Evol. 28:2731-2739.

Valli, A., López-Moya, J. J., and García, J. A. 2007. Recombination and gene duplication in the evolutionary diversification of $\mathrm{P} 1$ proteins in the family Potyviridae. J. Gen. Virol. 88:1016-1028.

Wallis, C. M., Stone, A. L., Sherman, D. J., Damsteegt, V. D., Gildow, F. E., and Schneider, W. L. 2007. Adaptation of Plum pox virus to a herbaceous host (Pisum sativum) following serial passages. J. Gen. Virol. 88:2839-2845.
Wen, R. H., Maroof, M. A., and Hajimorad, M. R. 2011. Amino acid changes in P3, and not the overlapping pipo-encoded protein, determine virulence of Soybean mosaic virus on functionally immune Rsv1-genotype soybean. Mol. Plant Pathol. 12:799-807.

Zhang, C., Hajimorad, M. R., Eggenberger, A. L., Tsang, S., Whitham, S. A., and Hill, J. H. 2009. Cytoplasmic inclusion cistron of Soybean mosaic virus serves as a virulence determinant on Rsv3-genotype soybean and a symptom determinant. Virology 391:240-248.

\section{AUTHOR-RECOMMENDED INTERNET RESOURCE}

The SharCo Plum pox virus database: w3.pierroton.inra.fr:8060 